\author{
Alicja Zemanek \\ Ogród Botaniczny \\ Instytut Botaniki UJ \\ alicja.zemanek@uj.edu.pl

\section{Piotr Köhler} \\ Zakład Badań i Dokumentacji Polarnej im. prof. Z. Czeppego \\ Instytut Botaniki UJ \\ piotr.kohler@uj.edu.pl
}

\title{
Historia Ogrodu Botanicznego Uniwersytetu Stefana Batorego w Wilnie (1919-1939)
}

\begin{abstract}
Streszczenie
Ogród Botaniczny Uniwersytetu w Wilnie był łącznie przez ponad 70 lat placówką należącą do botaniki polskiej. Utworzony w $1781 \mathrm{r}$. przez Jeana Emmanuela Giliberta (1741-1814), w praktyce funkcjonujący od 1782 r., działał do 1842 r., kiedy to został zlikwidowany przez rosyjskiego zaborcę.

W 1919 r. założono w nowym miejscu Ogród Botaniczny Uniwersytetu Stefana Batorego (czynny od 1920 r.), pełniący funkcję zakładu pomocniczego dwóch zakładów (katedr) botanicznych. Organizatorem i pierwszym dyrektorem był w latach 1920-1923 fizjolog roślin - Piotr Wiśniewski (1884-1971).
\end{abstract}

\begin{tabular}{|c|c|c|c|c|c|}
\hline \multicolumn{2}{|c|}{$\begin{array}{l}\text { INFORMACJA } \\
\text { O PUBLIKACJI }\end{array}$} & Pistoriae & $\begin{array}{r}\text { e-ISSN 2543-702X } \\
\text { ISSN 2451-3202 }\end{array}$ & 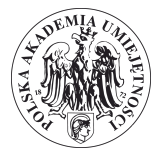 & $\begin{array}{l}\bigodot \\
\text { BRYLANTOWY MODEL } \\
\text { OTWARTEGO DOSTĘPU }\end{array}$ \\
\hline \multicolumn{6}{|c|}{ 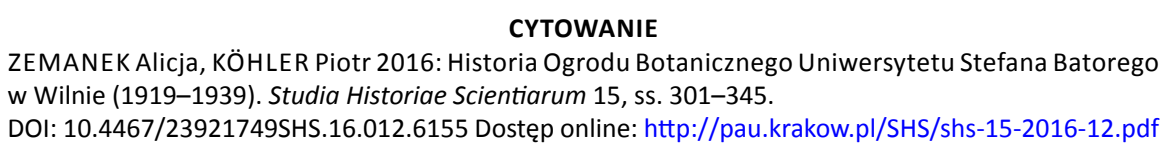 } \\
\hline \multicolumn{3}{|c|}{$\begin{array}{l}\text { OTRZYMANO: } 21.12 .2015 \\
\text { ZAAKCEPTOWANO: } 12.10 .2016 \\
\text { OPUBLIKOWANO ONLINE: } \mathbf{2 4 . 1 1 . 2 0 1 6}\end{array}$} & $\begin{array}{c}\text { POLITYKA } \\
\text { ARCHIWIZOWANIA } \\
\frac{\text { Green SHERPA/ }}{\text { RoMEO Colour }}\end{array}$ & $\begin{array}{l}\text { LICENCJA } \\
\text { (C) }(1) \Theta(\Theta)\end{array}$ & \\
\hline WWW & \multicolumn{5}{|c|}{ http://pau.krakow.pl/Studia-Historiae-Scientiarum/ http://ejournals.eu/Studia-Historiae-Scientiarum } \\
\hline
\end{tabular}


W latach 1924-1937 kierownictwo sprawował Józef Trzebiński (1867-1941) - mykolog, jeden z twórców polskiej fitopatologii, a w latach 1937-1939 - Franciszek Ksawery Skupieński (18881962) - badacz śluzowców.

Dla rozwoju Ogrodu duże zasługi położył główny ogrodnik, czyli inspektor Konstanty Prószyński (Proszyński; 1859-1936), były właściciel ziemski, przyrodnik amator, autor jednej publikacji mykologicznej, zatrudniony w latach 1919-1936. Ogród, obejmujący ok. 2 ha, usytuowany był w zakolu rzeki Wilii zwanym Zakretem (po litewsku Vingis), poza centrum miasta. Mimo trudności finansowych założono tutaj działy roślin analogiczne do istniejących w innych ogrodach botanicznych: systematyki ogólnej, flory krajowej, roślin piaskowych (psammofilnych), roślin uprawnych, ekologii roślin, alpinarium, torfowisko wysokie, a także arboretum oraz gatunki wodne i błotne.

W latach 1926-1929 wybudowano szklarnię dla uprawy roślin ciepłych stref klimatycznych. Grupy ilustrujące roślinność różnych typów siedlisk odzwierciedlały rozwój ekologii i fitosocjologii w nauce tego okresu. Liczba uprawianych gatunków wzrastała w miarę upływu czasu: od 1347 w latach 1923/1924 do ok. 2800 w okresie 1936/1937. Począwszy od 1923 r. zaczęto wydawać drukowane katalogi nasion. Prowadzono tutaj doświadczenia do prac naukowych, m.in. z zakresu fitopatologii. Kolekcje roślin wykorzystywano w czasie zajęć ze studentami, a także do edukacji młodzieży szkolnej i szerokiej publiczności.

Po przyłączeniu Wilna do Litwy w 1939 r. władze litewskie zamknęły Uniwersytet Stefana Batorego, kończąc tym samym historię polskiego ogrodu botanicznego. Obecnie jego teren jest jednym z działów Ogrodu Botanicznego Uniwersytetu Wileńskiego (dział „Vingis” - Vilniaus universiteto botanikos sodas). Nadal służy studentom i mieszkańcom miasta, a kwitnące rośliny używane są do ozdabiania uniwersyteckich sal i uświetniania uroczystości.

Słowa kluczowe: Ogród Botanicæny w Wilnie • Uniwersytet Stefana Batorego w Wilnie - kolekcje roślin • nauczanie botaniki • Jean Emmanuel Gilibert • Konstanty Prószyński (Proszyński) - Franciszeke Ksawery Skupieński • Józef Trzebinski • Piotr Wiśniewski 


\title{
History of the Botanic Garden of the Stefan Batory University in Vilna (Vilnius) (1919-1939)
}

\begin{abstract}
The university in Vilna (Lithuanian: Vilnius), now Vilniaus universitetas, founded in 1579 by Stefan Batory (Stephen Báthory), King of Poland and Grand Duke of Lithuania, was a centre of Polish botany in 1780-1832 and 1919-1939. The Botanic Garden established by Jean Emmanuel Gilibert (1741-1814) in 1781 (or, actually, from 1782) survived the loss of independence by Poland (1795), and a later closure of the University (1832), and it continued to function until 1842, when it was shut down by Russian authorities. After Poland had regained independence and the University was reopened as the Stefan Batory University (SBU), its Botanic Garden was established on a new location (1919, active since 1920). It survived as a Polish institution until 1939. After the Second World War, as a result of changed borders, it found itself in the Soviet Union, and from 1990 - in the Republic of Lithuania.

A multidisciplinary research project has been recently launched ${ }^{1}$ with the aim to create a publication on the history of science at the Stefan Batory University. The botanical part of the project includes, among others, drafting the history of the Botanic Garden. Obtaining electronic copies of archival documents, e.g. annual reports written by the directors, enabled a more thorough analysis of the Garden's history.

Piotr Wiśniewski (1884-1971), a plant physiologist, nominated as Professor in the Department of General Botany on 1 June 1920, was the organiser and the first director of the Garden. He resigned from his post in October 1923, due to financial problems of the Garden. From October 1923 to April 1924, the management was run by the acting director, Edward Bekier (1883-1945), Professor in the Department of Physical Chemistry, Dean of the Faculty of Mathematics and Natural Sciences. For 13 subsequent years, i.e. from 1 May 1924 to 30
\end{abstract}

${ }^{1}$ Research Project NPRH/912-Bibl: HINC ITUR AD ASTRA executed by Nicolaus Copernicus University in Toruń (supervisor: prof. Mirosław Supruniuk) in cooperation with Vilnius University. 


\section{Alicja Zemanek, Piotr Köhler}

Historia Ogrodu Botanicznego Uniwersytetu Stefana Batorego w Wilnie...

April 1937, the directorship of the Garden was held by Józef Trzebiński (1867-1941), a mycologist and one of the pioneers of phytopathology in Poland, Head of the Department of Botany II (Agricultural Botany), renamed in 1926 as the Department of Plant Taxonomy, and in 1937 - the Department of Taxonomy and Geography of Plants.

From May 1937 to 1939, his successor as director was Franciszek Ksawery Skupieński (1888-1962), a researcher of slime moulds.

Great credit for the development of the Garden is due to the Inspector, i.e. Chief Gardener, Konstanty Prószyński (Proszyński) (1859-1936) working there from 1919, through his official nomination in 1920, until 1936. He was an amateurnaturalist, a former landowner, who had lost his property. Apart from the work on establishing and maintaining the Garden's collection, as well as readying seeds for exchange, he published one mycological paper, and prepared a manuscript on fungi, illustrated by himself, containing descriptions of the new species. Unfortunately, this work was not published for lack of funds, and the prepared material was scattered. Some other illustrations of flowering plants drawn by Prószyński survived. There were some obstacles to the further development of the institution, namely substantially inadequate funds as well as too few members of the personnel (1-3 gardeners, and 1-3 seasonal workers).

The area of the Garden, covering approx. 2 hectares was situated on the left bank of the Neris river (Polish: Wilia). It was located on sandy soils of a floodplain, and thus liable to flooding. These were the reasons for the decision taken in June 1939 to move the Garden to a new site but the outbreak of the Second World War stood in the way. Despite these disadvantageous conditions, the management succeeded in setting up sections of plants analogous to these established in other botanical gardens in Poland and throughout the world, i.e. general taxonomy (1922), native flora (1922), psammophilous plants (1922), cultivated plants (1924/1925), plant ecology (1927/1928), alpinarium (1927-1929), high-bog plants (1927-1929), and, additionally - in the 1920s - the arboretum, as well as sections of aquatic and bog plants. A glasshouse was erected in 1926-1929 to provide room for plants of warm and tropical zones. The 
groups representing the various types of vegetation illustrated the progress in ecology and phytosociology in the science of the period (e.g. in the ecology section, the Raunkiaer's life forms were presented). The number of species grown increased over time, from 1,347 in 1923/1924 to approx. 2,800 in 1936/1937. Difficult weather conditions - the severe winter of 1928 as well as the snowless winter and the dry summer of 1933/1934 contributed to the reduction of the collections. The ground collections, destroyed by flood in spring of 1931, were restored in subsequent years. Initially, the source of plant material was the wild plant species collected during field trips. Many specimens were also obtained from other botanical gardens, such as Warsaw and Cracow (Kraków). Beginning from 1923, printed catalogues of seeds offered for exchange were published (cf. the list on pp. 335-336). Owing to that, the Garden began to participate in the national and international plant exchange networks. From its inception, the collection of the Garden was used for teaching purposes, primarily to the students of the University, as well as for the botanical education of schoolchildren and the general public, particularly of the residents of Vilna. Scientific experiments on phytopathology were conducted on the Garden's plots.

After Vilna was incorporated into Lithuania, Stefan Batory University, thus ending the history of the Polish Botanic Garden was shut down on 15 December 1939. Its area is now one of the sections of the Vilnius University Botanic Garden ("Vingis" section - Vilniaus universiteto botanikos sodas). In 1964, its area was extended to 7.35 hectares. In 1974, after establishing the new Botanic Garden in Kairenai to the east of Vilnius, the old Garden lost its significance. Nevertheless, it still serves the students and townspeople of Vilnius, and its collections of flowering plants are often used to decorate and grace the university halls during celebrations.

Keywords: Botanic Garden in Vilna (Wilno, Vilnius) - Stefan Batory University • plant collections $\bullet$ teaching botany $\bullet$ Jean Emmanuel Gilibert

- Konstanty Prószyński (Proszyński) - Franciszek Ksawery Skupieński

- Józef Trzebinski • Piotr Wiśniewski 


\section{Wprowadzenie}

Zmienne losy Ogrodu Botanicznego w Wilnie związane są z burzliwą historią samego miasta, jak i Uniwersytetu Wileńskiego założonego w 1579 r. dzięki fundacji króla Stefana Batorego. Ogród, który został utworzony przez Jeana Emmanuela Giliberta (1741-1814) w 1781 r. (praktycznie istniał od 1782 r.) w wyniku reformy Akademii Wileńskiej w czasach Komisji Edukacji Narodowej, przetrwał utratę niepodległości kraju, a następnie zamknięcie Uniwersytetu i funkcjonował aż do 1842 r., kiedy to został zlikwidowany przez rosyjskiego zaborcę. Po odzyskaniu niepodległości przez Polskę i wskrzeszeniu w 1919 r. uczelni pod nazwą Uniwersytetu Stefana Batorego (USB), uniwersytecki ogród botaniczny założony został w nowym miejscu. Utrzymał się jako polska instytucja do 1939 r. Po II wojnie światowej w następstwie zmiany granic wraz z całym miastem znalazł się w ZSRR, a od 1990 r. w Republice Litewskiej. Obecnie jego teren jest jednym z działów Ogrodu Botanicznego Uniwersytetu Wileńskiego i funkcjonuje pod nazwą „Vingis” Vilniaus universiteto botanikos sodas.

Początki polskiego ogrodu botanicznego, który pod koniec XVIII i w pierwszej połowie XIX w. stał się ważnym ośrodkiem naukowo-dydaktycznym, są stosunkowo dobrze zbadane ${ }^{2}$. Na temat historii zakładu w okresie dwudziestolecia międzywojennego wiadomo niewiele, głównie dzięki artykułom wspomnieniowym wychowanka i pracownika wileńskiej uczelni Jakuba Mowszowicza (1901-1983), którego prace przywoływane są w dalszej części tego tekstu. Trwający od kilku lat interdyscyplinarny projekt badawczy prowadzony przez Uniwersytet Mikołaja Kopernika w Toruniu (kierownik prof. Mirosław Supruniuk) we współpracy z Uniwersytetem $\mathrm{w}$ Wilnie ${ }^{3}$ ma na celu opracowanie źródłowe historii nauki w USB. Dzięki uzyskaniu elektronicznych kopii dokumentów archiwalnych, głównie sprawozdań rocznych pisanych przez dyrektorów Ogrodu, można było dokładniej przeanalizować

${ }^{2}$ Grębecka 1988, o Ogrodzie Botanicznym - ss. 179-182; Grębecka 1979; Grębecka 1993; Grębecka 1998; Jundziłł 1850; Köhler 1991; Köhler 1995a; Köhler 2011; L.R. 1871; Mowszowicz 1948-1951 [wyd. 1951]; Skridaila 2001; Skridaila, Naujalis 2002; Skridaila, Žilinskaite, Shiyan 2015; Sławiński 1947; Wodziczko 1926.

${ }^{3}$ Grant NPRH/912-Bibl: HINC ITUR AD ASTRA. Uniwersytet Stefana Batorego w Wilnie 1919-1939. Monografia zespołowa. 
jego dzieje. Lektura owych sprawozdań odsłania kulisy mozolnej, codziennej pracy w szczególnej jednostce naukowej, jaką jest ogród botaniczny. Obrazuje też niełatwy czas odradzania się wileńskiego ośrodka botanicznego (praktycznie stworzono go od nowa), gdy osobiste zaangażowanie botaników i ogrodników musiało zmagać się z rozmaitymi trudnościami.

Wskrzeszaniu botaniki wileńskiej w 1919 r. towarzyszyła żywa pamięć świetnej przeszłości studiów przyrodniczych z końca XVIII i pierwszej połowy XIX w., kiedy to ukształtowała się pierwsza na ziemiach polskich wileńsko-krzemieniecka botaniczna szkoła naukowa. Pracujący w niej tacy botanicy, jak wspomniany powyżej Jean Emmanuel Gilibert, Stanisław Bonifacy Jundziłł (1761-1847) czy Józef Jundziłł (1794 1877) i inni, przyczynili się do ukształtowania metodyki terenowych badań florystycznych, a z ich prac - uznanych za klasyczne - korzystali badacze następnych generacji ${ }^{4}$. Jak pisał wiele lat później Jakub Mowszowicz:

Pomiędzy poszczególnymi etapami rozwojowymi Uniwersytetu Wileńskiego pozostawał żywy związek. Również w działalności naukowej na polu botaniki te więzy istniały ${ }^{5}$.

Prace przygotowawcze i organizacyjne związane z uruchomieniem studiów, pierwszej katedry botanicznej oraz samego ogrodu botanicznego rozpoczął Piotr Wiśniewski (1884-1971), dziekan Wydziału Matematyczno-Przyrodniczego i współorganizator uczelni. Grunt wybrano w 1919, Ogród rozpoczął działalność w 1920 roku. O dokonanym wyborze terenu pisał później geolog i senator RP Bronisław Rydzewski (1884-1945):

Ogród botaniczny dawnego Uniwersytetu Wileńskiego, z którym wiązało się tyle pięknych tradycyj naukowych, z którym związane były najwybitniejsze nazwiska dawnych botaników wileńskich, był w stanie takim i tak położony, że o wykorzystaniu i rewindykacji jego na rzecz

${ }^{4}$ Np.: Grębecka 1988; Köhler 1991; 1994a-1994e; 1995b; 1995c; 1997a-1997c; 1999; 2004.

${ }^{5}$ Mowszowicz 1966, s. 100. 
Uniwersytetu nie można było myśleć. Należało szukać nowego terenu, a to tem bardziej, że dzisiaj ogrody botaniczne rozrastają się do wielkich rozmiarów, zajmując znaczne przestrzenie pól. Trzeba było nie tylko założyć ten ogród, lecz równocześnie tak go umieścić, aby miał on wszelakie dane dla dalszego rozwoju. Jedyny botanik ówczesny, prof. dr. P. Wiśniewski, zwrócił uwagę na folwark Zakret, oddany do dyspozycji U.S.B. Na mocy uchwały Rady wydziałowej i Senatu przydzielono ogrodowi w folwarku Zakret około dwóch hektarów ziemi, odgrodzonej od strony Wilji wysokim murem. Równocześnie Senat zastrzegł dla ogrodu botanicznego prawo dalszego zajmowania terenów przyległych, o ile zajdzie tego potrzeba.

[...] Teren ogrodu przedstawia płaska, bardzo nisko położoną równinę (zalewowa terasa Wilji), ma glebę piaszczysta, o płytkiej wodzie zaskórnej, jest otwarty i niezabezpieczony od zimnych wiatrów północnych. Warunki zatem sa niezbyt dogodne dla uprawy roślin, wynagradza je natomiast długa kultura rolna tego terenu ${ }^{6}$.

Była to już trzecia lokalizacja Ogrodu Botanicznego w Wilnie. Pierwszy założony przez Giliberta usytuowany był w środku miasta, na niewielkim dziedzińcu Collegium Medicum. Drugi, znacznie obszerniejszy zaaranżowany w czasach Stanisława Bonifacego Jundziłła, mieścił się nad Wilenką w dzielnicy Sorokiszki. Trzeci, wybrany przez Wiśniewskiego obszar, położony był na lewym brzegu Wilii, w malowniczym zakolu rzeki określanym nazwą Zakret (od słowa zakręt, po litewsku vingis), na terenie podmiejskiej dzielnicy Wilcza Lapa ${ }^{8}$. W XVI w. teren należał do Radziwiłłów, którzy wybudowali tu drewniany dwór, przekazany pod koniec stulecia jezuitom. W XVIII w. nowi właściciele wznieśli trzypiętrowy pałac oraz założyli ogrody, dzięki czemu powstała piękna letnia rezydencja. Była ona jednym z kulturalnych centrów miasta nazywanym „wileńskim Wersalem”. Od XVII w. istniał tam również ogród roślin leczniczych dostarczający surowców do wyrobu

\footnotetext{
${ }^{6}$ Rydzewski 1929, s. 336 (64).

${ }^{7}$ Baliński 1835, s. 99.

${ }^{8}$ Köhler 1995a.
} 
leków sprzedawanych w jezuickiej aptece. Po kasacie zakonu rezydencja zmieniała właścicieli, ulegając stopniowej degradacji. W połowie XIX w. zniszczony pałac został rozebrany'. W 1919 r. funkcjonowało na Zakrecie gospodarstwo rolne (folwark), które przekazano odrodzonemu Uniwersytetowi.

\section{Początki Ogrodu 1919-1923}

Entuzjazmowi w reaktywacji uczelni towarzyszyła konieczność przezwyciężenia wielu trudności natury politycznej, finansowej, personalnej i lokalowej ${ }^{10}$. Pierwszym dyrektorem Ogrodu Botanicznego został wspomniany wyżej Piotr Wiśniewski (Ryc. 1), mianowany profesorem

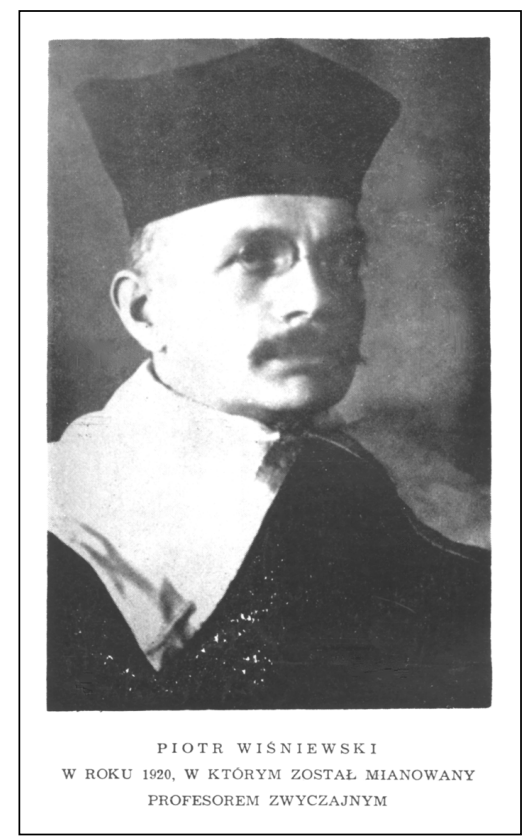

Ryc. 1. Piotr Wiśniewski (1884-1971) (Paszewski 1971, k. 1 nlb.)

Fig. 1. Piotr Wiśniewski (1884-1971) (Paszewski 1971, leaf 1, unnumered)

${ }^{9}$ Chlebowski 1895, s. 312; Portal internetowy „Poznaj Wilno” 2014-2015.

${ }^{10}$ Mienicki 1929, s. 125(11). 
USB od 1 czerwca $1920^{11}$. Był organizatorem i kierownikiem Zakładu (Katedry) Botaniki Ogólnej. Przybył do Wilna z Warszawy, gdzie był wcześniej profesorem botaniki w Szkole Głównej Gospodarstwa Wiejskiego. Był to fizjolog roślin wykształcony w Cesarskim Uniwersytecie Warszawskim, Uniwersytecie Jagiellońskim i Uniwersytecie w Odessie. Doktorat $z$ anatomii eksperymentalnej uzyskał w Uniwersytecie Lwowskim pod kierunkiem Mariana Raciborskiego (1863-1917), później przebywał w holenderskich i niemieckich zakładach naukowych, m.in. w Heidelbergu ${ }^{12}$. W czasie pobytu w Wilnie prowadził badania fizjologiczne m.in. nad okresem spoczynkowym gatunków wodnych, eksplorował też roślinność Wileńszczyzny ${ }^{13}$. Piotr Wiśniewski prawdopodobnie już od 1 IX 1919 r. nieformalnie kierowal pracami nad organizacją Ogrodu Botanicznego. W zachowanych materiałach archiwalnych brak informacji o powołaniu go na dyrektora tej placówki. Datę 1 VI 1920 r., gdy został mianowany profesorem, trzeba przyjąć za oficjalne objęcie funkcji profesora w katedrze i równocześnie dyrektora Ogrodu Botanicznego.

Przez cały czas istnienia Ogrodu liczba personelu mającego pomagać dyrektorowi była bardzo skromna. Oprócz inspektora, czyli głównego ogrodnika, pracowało tu rocznie od jednego do dwóch ogrodników, rzadziej trzech, przy czym wiosną i latem angażowano pracowników sezonowych, maksymalnie trzy osoby. $\mathrm{Na}$ stanowiskach ogrodników lub starszych ogrodników pracowali (w porządku alfabetycznym): Antoni Jasiński, Bolesław Korkuć i Zbigniew Wiewiórka; jako „robotnicy stali” (rzemieślnicy): Paweł Kowalewski, Adam Żemojtel; furman Józef Matuszyński oraz stróż Józef Stankiewicz ${ }^{14}$.

${ }^{11}$ Lietuvos Centrinis Valstybès Archyvas [Litewskie Centralne Archiwum Państwowe] (dalej cyt. LCVA) Akta Uniwersytetu Stefana Batorego w Wilnie (wszystkie dalej cytowane archiwalia pochodzą z tego jednego zespołu, więc skrót jego nazwy nie będzie używany): sygn. F. 175 I Bb nr 784 - Akta osobowe Piotr Wiśniewski.

${ }^{12}$ Paszewski 1971.

${ }^{13}$ Mowszowicz 1973.

${ }^{14} \mathrm{Na}$ podstawie drukowanych spisów zakładów, pracowników i wykładów USB, wydawanych prawie co roku, w różnych wersjach i pod różnymi tytułami, np. Universitas Vilnensis Batoreana. Uniwersytet Stefana Batorego w Wilnie. Istnienia W szechnicy rok 256. III Spis wyktadów i Sketad Uniwersytetu w roku akademickim 1920/21, cytowanych dalej jako [Skład USB]. 


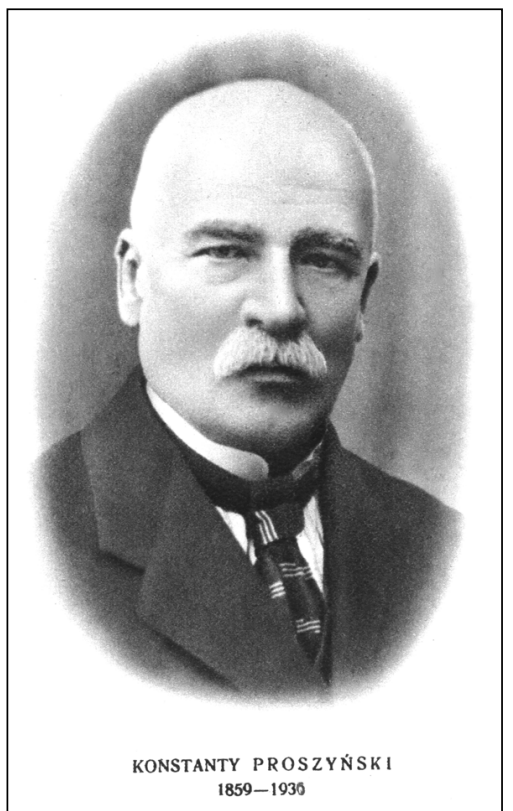

Ryc. 2. Konstanty Prószyński (Proszyński) (1859-1936) (Wiśniewski 1938, k. 1 nlb.)

Fig. 2. Konstanty Prószyński (Proszyński) (1859-1936)

(Wiśniewski 1938, leaf 1, unnumered)

Dla rozwoju Ogrodu duże zasługi położył inspektor Konstanty Prószyński (Proszyński) (1859-1936) (Ryc. 2) pracujący już od 1919 r., a oficjalnie mianowany 1 marca $1920 \mathrm{r}$. (początkowo jako zastępca inspektora $)^{15}$. Odgrywał on pierwszoplanową rolę przy projektowaniu i praktycznym tworzeniu działów, a później przy utrzymaniu kolekcji roślin oraz przygotowywaniu nasion do wymiany. Był niegdyś właścicielem ponad tysiąchektarowego majątku ziemskiego Dubica, położonego na terenie gminy Czuczewicze w guberni mińskiej, filantropem nieszczędzącym wydatków na cele patriotyczne i społeczne. Studiował przez dwa lata nauki przyrodnicze na Cesarskim Uniwersytecie Warszawskim, później systematycznie poszerzał wiedzę we własnym zakresie. Przez rok uczył historii i łaciny w szkołach średnich w Mińsku.

${ }^{15}$ LCVA sygn. F. 175 VII B nr 53 [Protokół z 14. posiedzenia Rady Wydz. Mat.Przyr. z dn. 28 lutego 1920 r.]. 


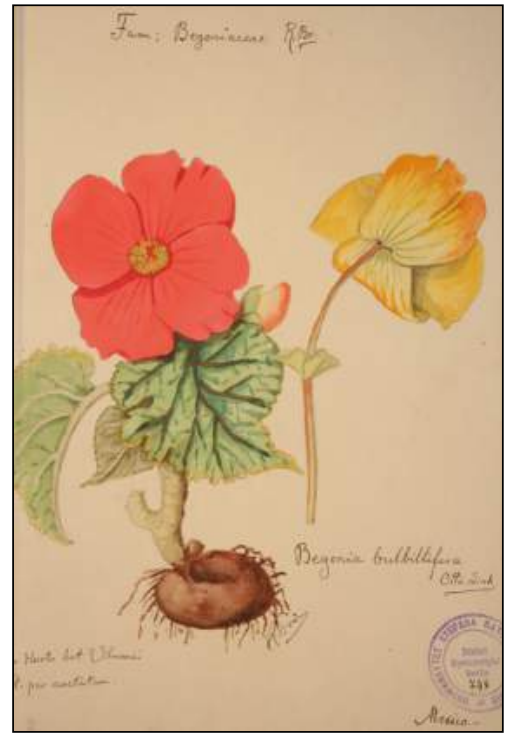

Ryc. 3. Begonia bulbillifera (obecnie Begonia bulbifera hort. ex E.Vilm.) - obraz malowany przez Konstantego Prószyńskiego. Ze zbiorów Vilniaus universiteto botanikos sodas

Fig. 3. Begonia bulbillifera (now Begonia bulbifera hort. ex E.Vilm.) - picture by Konstanty Prószyński. From the collecion of Vilniaus universiteto botanikos sodas

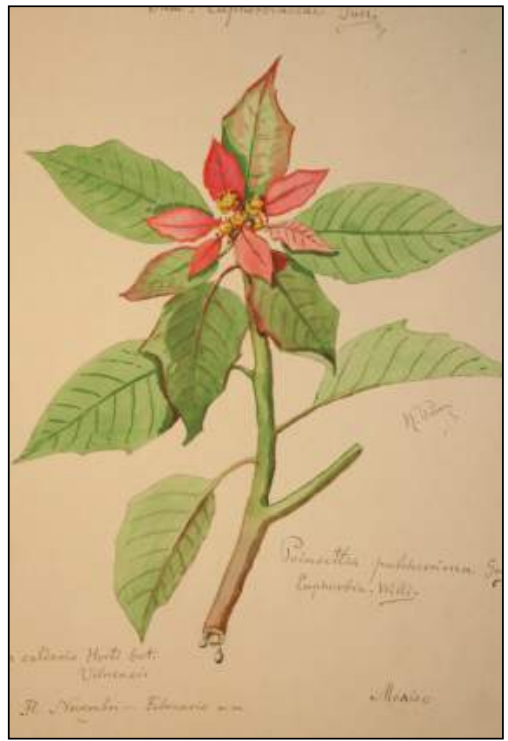

Ryc. 4. Poinsettia pulcherrima (obecnie Euphorbia pulcherrima Willd. ex Klotzsch) obraz malowany przez Konstantego Prószyńskiego. Ze zbiorów Vilniaus universiteto botanikos sodas.

Fig. 4. Poinsettia pulcherrima (now Euphorbia pulcherrima Willd. ex Klotzsch) - picture by Konstanty Prószyński. From the collecion of Vilniaus universiteto botanikos sodas

Po utracie majątku został bez środków materialnych. W nowo tworzonym ogrodzie wileńskim otrzymał zatrudnienie i mieszkanie, gdzie spędził wraz z rodziną resztę życia. Mimo że był tylko przyrodnikiem amatorem, znakomicie pełnił swoje obowiązki. Posiadał nie tylko dobra znajomość roślin kwiatowych, ale był też nieprzeciętnym znawcą grzybów kapeluszowych. Opublikował z tego zakresu jedną obszerna pracę zawierającą opisy nowych gatunków. Miał duże zdolności plastyczne i z zamiłowaniem malował portrety roślin uprawianych w Ogrodzie - kilkadziesiąt z nich znajduje się obecnie w zbiorach Vilniaus universiteto botanikos sodas (Ryc. 3-4). Klikaset arkuszy obrazów dziko rosnących gatunków przechowywanych jest w uniwersyteckim Herbarium. Rozproszeniu uległ niezwykle cenny zbiór wizerunków grzybów kapeluszowych z opisami po łacinie (którą Prószyński biegle władał), zawie- 
rający prawdopodobnie opisy wielu nowych gatunków. Niestety, przygotowywane duże ilustrowane dzieło o grzybach nie ujrzało nigdy światła dziennego z braku środków finansowych na wydanie ${ }^{16}$. Piotr Wiśniewski pisał o działalności Prószyńskiego w Ogrodzie:

[...] pracował z właściwą sobie ofiarnością i sumiennością prawie od chwili założenia Ogrodu i pomimo licznych trudności i bardzo skapych środków finansowych, jakie miał do rozporządzenia, potrafil zorganizować i utrzymać szereg ciekawych kolekcji roślinnych ${ }^{17}$.

J. Mowszowicz wspominał po latach:

Z dużą pasjąinspektor K. Prószyński przykładał się do rozwoju umiłowanego przez siebie Ogrodu. Mieszkając przy Ogrodzie, ciagle w nim przebywał i doglądał go. W ciagu siedemnastoletniej (1919 do 1936) nieprzerwanej pracy w Wileńskim Ogrodzie Botanicznym - K. Prószyński ciągle go rozszerzał i wzbogacał. Celem powiększenia zbiorów często wyjeżdżał w teren, gdzie zbierał dziko rosnące okazy flory wileńskiej ${ }^{18}$.

Nowo utworzony Ogród uzyskał służbowe budynki, w których urządzono pracownię, pomieszczenia gospodarcze i mieszkania pracowników. Opisał je Rydzewski, podając również informacje na temat inwentarza:

Do dyspozycji ogrodu botanicznego oddany został drewniany dom - willa. W domu tym mieści się mieszkanie dyrektora ogrodu botanicznego, oraz na pierwszym piętrze podręczna pracownia botaniczna $z$ pokojem do zbierania i czyszczenia nasion, tudzież czasowem muzeum. Lokal na piętrze ma tak cienkie ściany, że niepodobna go opalić, $\mathrm{z}$ tego więc powodu praca $\mathrm{w}$ nim możliwa jest jedynie w lecie (od kwietnia do września). Oprócz wspomnianej willi personel ogrodu botanicznego korzysta z domu folwarcznego, gdzie mieści się mieszkanie inspektora ogrodu

${ }^{16}$ LCVA sygn. F. 175. I Bb nr 41 - Akta osobowe Konstanty Prószyński; Mowszowicz 1966, s. 114-115; Wiśniewski 1938.

${ }^{17}$ Wiśniewski 1938, s. XXVIII.

${ }^{18}$ Mowszowicz 1966, s. 114. 
i służby niższej. Wreszcie w skład ubikacyj, zajętych przez ogród botaniczny, wchodzą: składzik na narzędzia, stajnia i wozownia. W samym ogrodzie urządzone są inspekta na 12 okien.

Inwentarz ogrodu stanowi niezależną od zakładów botanicznych całość; wchodzą do niego najniezbędniejsze narzędzia gospodarcze, meble, para koni. $Z$ aparatów do pracy naukowej wymienić należy 4 mikroskopy oraz 37 modeli wyższych grzybów. Podręczna biblioteka ogrodu składa się z 107 dzieł w 149 tomach $^{19}$.

Na wiosnę 1920 r. założono pierwsze kwatery z roślinami zielnymi oraz drzewami z materiału otrzymanego z Ogrodu Botanicznego Uniwersytetu Warszawskiego. Niestety, zawiązki kolekcji zostały zniszczone. „W czasie inwazji bolszewicko-litewskiej na grządkach ogrodu pasano bydło, etykiety powyrywano, słowem zniszczono całoroczną pracę i zburzono zbiór rzadkich okazów" ${ }^{20}$, stąd też wiosną następnego roku trzeba było odtwarzać zniszczone działki. Jedna z pierwszych, koniecznych inwestycji było odnowienie zrujnowanego muru otaczajacego Ogród, ale z braku funduszów sprawa ciagnęła się przez wiele lat. W dniu 21 września 1921 r. dyrektor Wiśniewski pisał:

Kierownik Zakładu i Ogrodu Botanicznego prof. Wiśniewski stwierdza, że nie posiadając oddzielnych funduszów na remont składa z siebie odpowiedzialność [za] całość murów okalających ogród w Zakrecie, o ile przed zimą mur ten nie zostanie przynajmniej podparty palami ${ }^{21}$.

Na posiedzeniu Rady Wydziału 24 kwietnia 1923 r. prof. Wiśniewski zgłosił rezygnację (od 1 listopada) z kierownictwa Ogrodu „wobec trudnościbudżetowych"22 . Rezygnacja została przyjęta, a 22 października

${ }^{19}$ Rydzewski 1929, s. 337(65).

${ }^{20}$ Mienicki 1929, s. 122 (8).

${ }^{21}$ LCVA sygn. F. 175 VII B nr 55 [Protokół I posiedzenia Rady Wydziałowej Wydz. Mat.-Przyr. i Lekar. USB z dnia 21 września 1921 r., p. 22. Sprawa remontu ogrodzenia Ogrodu Botanicznego].

${ }^{22}$ LCVA sygn. F. 175 VII B nr 56 [Protokół nr 16 posiedzenia Rady Wydz. Mat.-Przyr. USB z dnia 24 kwietnia 1923 r., p. 5. Sprawa rezygnacji prof. Wiśniewskiego z kierownictwa Ogrodu Botanicznego]. 


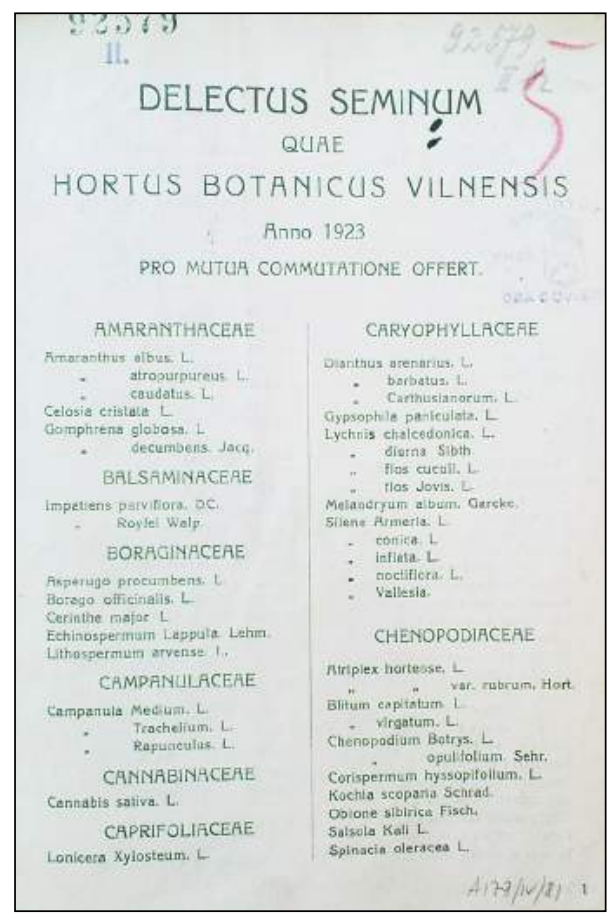

Ryc. 5. Strona tytułowa katalogu nasion wydanego w $1923 \mathrm{r}$. (Biblioteka Jagiellońska, sygn. 92579 II)

Fig. 5. Title-page of the seed catalogue published in 1923 (Jagiellonian Library, signature 92579 II)

1923 r. ${ }^{23}$ powierzono tymczasowe kierownictwo dziekanowi Wydziału Matematyczno-Przyrodniczego Edwardowi Bekierowi (1883-1945) - profesorowi Zakładu (Katedry) Chemii Fizycznej. Dużym sukcesem inspektora Prószyńskiego było wydanie (wspólnie z Bekierem) w 1923 r. pierwszego katalogu nasion pt. Delectus seminum quae hortus botanicus vilnensis Anno 1923 pro mutua commutatione offert. Katalog oferujący do wymiany nasiona 306 gatunków (oraz kilku odmian) (Ryc. 5) przyczynił się do nawiązania kontaktów z innymi ogrodami botanicznymi w Polsce i na świecie. Dzięki temu zaczęto otrzymywać w następnych latach

${ }^{23}$ LCVA sygn. F. 175 VII B nr 57 [Protokół nr 4 posiedzenia Rady Wydz. Mat.Przyr. USB z dnia 22 października 1923 r., p. 7. Sprawa kierownictwa Ogrodu Botanicznego]. 
materiał roślinny (siewny) pochodzący z różnych regionów geograficznych, co sprawiło, że zbiory zaczęły sukcesywnie wzrastać. Jeszcze w maju 1923 r. $^{24}$ zaplanowano w budżecie na 1924 rok budowę szklarni, jednak na realizację tego projektu trzeba było czekać kilka lat.

\section{Rozwój Ogrodu w latach 1924-1936}

Począwszy od 1 maja 1924 r. ${ }^{25}$, dyrektorem został prof. Józef Trzebiński (1867-1941) (Ryc. 6) kierownik i organizator Zakładu (Katedry) Botaniki II (Botaniki Rolniczej) przemianowanego w 1926 r. na Zakład

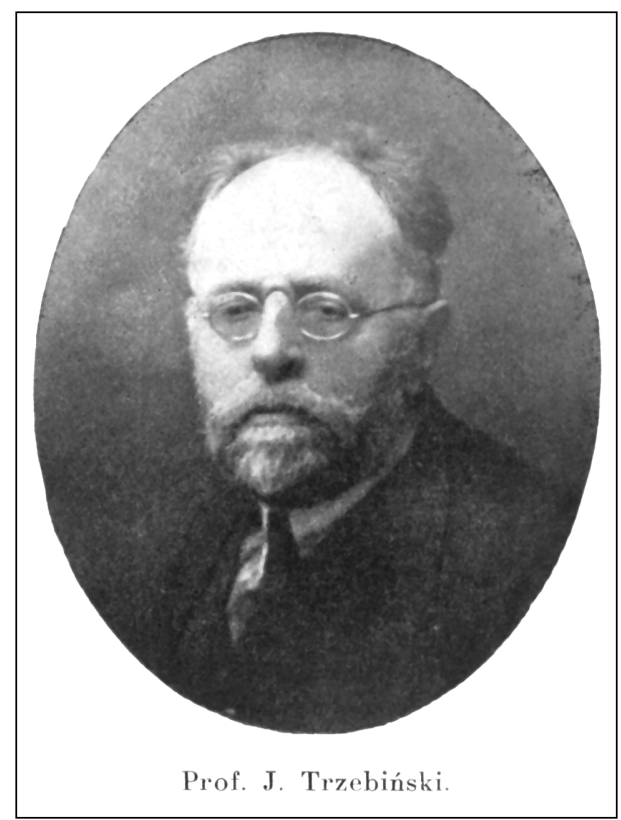

Ryc. 6. Józef Trzebiński (1867-1941) (Hryniewiecki 1937, k. 1 nlb.)

Fig. 6. Józef Trzebiński (1867-1941) (Hryniewiecki 1937, leaf 1, unnumered)

${ }^{24}$ LCVA sygn. F. 175 VII B nr 56 [Protokół nr 17 posiedzenia Rady Wydz. Mat.-Przyr. USB z dnia 1 maja 1923 r., p. 4. Wybór komisji do planowania Ogrodu Botanicznego].

${ }^{25}$ LCVA sygn. F. 175 VII B nr 57 [Protokół nr 19 posiedzenia Rady Wydz. Mat.-Przyr. USB z dnia 7 kwietnia 1924 r., p. 7]. 
Systematyki Roślinn ${ }^{26}$, a w 1937 r. - Systematyki i Geografii Roślin ${ }^{27}$ (w dalszej części tekstu zakład nazywany będzie w skrócie Zakładem Systematyki Roślin). Kierował Ogrodem do przejścia na emeryturę w 1937 r. Był jednym z twórców polskiej fitopatologii i uznanym mykologiem, specjalizującym się w grzybach pasożytniczych. Wychowanek uniwersytetów w Warszawie i Krakowie, uzyskał stopień kandydata nauk na Cesarskim Uniwersytecie Warszawskim, a doktorat i habilitację na Uniwersytecie Jagiellońskim. Wiedzę o grzybach zdobywał pod kierunkiem Wilhelma Pfeffera (1845-1920) na Uniwersytecie w Lipsku oraz Edwarda Janczewskiego (1846-1918) na UJ. Później pracował w różnych instytucjach, był m.in. kierownikiem Stacji Entomologicznej Wszechrosyjskiego Związku Cukrowników w Śmile w guberni kijowskiej, gdzie badał choroby roślin uprawnych, a po przeniesieniu do Warszawy - zorganizował Stację Ochrony Roślin. W czasie I wojny światowej pracowal jako inspektor Ogrodu Botanicznego w Warszawie, później został kierownikiem Wydziału Ochrony Roślin w Państwowym Instytucie Naukowym Gospodarstwa Wiejskiego w Puławach. Odwiedził w celach naukowych wiele krajów Europy oraz podróżował po Rosji. Oprócz grzybów bardzo dobrze znał florę roślin kwiatowych i publikował prace florystyczne. W Wilnie prowadził prace mykologiczne i fitopatologiczne, wydał podręcznik z fitopatologii, badał też m.in. zbiorowiska roślinne Jezior Trockich. Oprócz kierowania Ogrodem wiele czasu zajmowało mu prowadzenie Stacji Ochrony Roślin (przy Wileńskim Towarzystwie Organizacji i Kółek Rolniczych założonej w 1928 r., w 1933 przejętej przez nowo powstałą Wileńską Izbę Rolnicza) oraz jej Działu Mykologicznego działającego przy Zakładzie Systematyki Roślin ${ }^{28}$. Trzebiński wraz z rodziną zamieszkał początkowo w folwarku Zakret - „mieszkanie [miało] cechy mieszkania

${ }^{26}$ LCVA sygn. F. 175 VII B nr 59 [Protokół nr 10 z posiedzenia Rady Wydz. Mat.-Przyr. USB z dnia 13 stycznia 1926 r.].

${ }^{27}$ LCVA sygn. F. 175 VII B nr 161 [Protokół nr 17 z posiedzenia Rady Wydz. Mat.-Przyr. USB z dnia 25 maja 1937 r.]. W Składach USB pojawiają się nazwy: Zakład Botaniki II 1923/24, Zakład Morfologii i Systematyki Roślin 1924/25-1928/29, Zakład Systematyki Roślin 1929/30-1935/36, Zakład Systematyki i Geografii Roślin 1936/37-1938/39.

${ }^{28}$ Hryniewiecki 1937; Klimavičiute 1995; Majewski, 2016, ss. 97-98, 120 i inne strony; Rutkowska 1974. 
wiejskiego, a więc nie posiada[ło] ono wygód, gazu i elektryczności”, dopiero w $1931 \mathrm{r}$. profesor przeniósł się do centrum Wilna ${ }^{29}$.

W roku akademickim 1923/1924 Ogród posiadał 1182 gatunki roślin zielnych i 165 drzew i krzewów (razem: 1347 gatunków) posadzonych w następujących działach: systematyka ogólna roślin, flora krajowa, rośliny uprawne, drzewa i krzewy (arboretum). Nabyto ,przyrząd do polewania roślin”. Dyrektor Trzebiński wraz z inspektorem Prószyńskim podkreślali:

Natomiast skutkiem braku szklarni nie posiada ogród botaniczny żadnej kolekcji roślin krajów ciepłych i podzwrotnikowych, co jest wielką krzywdą dla młodzieży, która w ogóle nie może zaznajomić się bezpośrednio z przedstawicielami roślin krajów ciepłych. Niezbędnym jest także zwiększenie personelu niższego ogrodu botanicznego ${ }^{30}$.

$\mathrm{Na}$ terenie Ogrodu było kilka małych, standardowych szklarni. Dopiero w 1926 r. rozpoczęto budowę większej oranżerii, która początkowo nie posiadała ogrzewania z powodu braku pieniędzy. Pierwszy jej oddział oddany został do użytku w styczniu 1929 r., w maju przeniesiono tam rośliny z małej szklarni, która została później odnowiona. Drugi oddział zaczęto budować jeszcze w 1928 r. Roczne sprawozdanie z roku akademickiego 1926/1927 zawiera również wyszczególnienie najważniejszych prowadzonych prac i remontów:

Prace w ogrodzie botanicznym Uniwersytetu Wileńskiego obejmowały:

1. Zwykłe prace ogrodnicze: pielenie i podlewanie roślin gruntowych, czyszczenie ścieżek, przykrywanie roślin gruntowych na zimę i pielęgnowanie roślin szklarniowych.

2. Wysiewanie roślin, porządkowanie kolekcji roślin gruntowych (systematyka ogólna, flora krajowa, ekologia roślin i rośliny uprawne), pisanie etykietek.

3. Wymiana nasion $z$ innymi ogrodami botanicznymi. W tym celu wileński ogród botaniczny corocznie wydaje drukowany katalog nasion, który rozsyła się do innych ogrodów botanicznych.

\footnotetext{
${ }^{29}$ LCVA sygn. F. 175 I Bb nr 59 - Akta osobowe Józef Trzebiński.

${ }^{30}$ LCVA sygn. F. 175 I A nr 391 [Sprawozdanie z działalności Ogrodu botanicznego w ciagu roku akademickiego 1923/1924].
} 
4. Dostarczanie do Zakładu Systematyki Roślin materiału do ćwiczeń, badań naukowych i do muzeum.

5. Remont, względnie rozszerzenia urządzeń w ogrodzie botanicznym.

Znaczniejsze remonty: wyreperowano 9 małych basenów dla roślin wodnych i bagniskowych i dorobiono tyleż nowych basenów. Wyreperowano i pomalowano połowę dachu nad mieszkaniem dyrektora Ogrodu. Wyreperowano (kitowanie) małą i dużą szklarnię. Urządzono w ogrodzie botanicznym ustęp. Ważniejsze nabytki w ogrodzie botanicznym: Zakupiono do biblioteki ogrodu 4 tomy nowego wydania Engler und Prantl - Natürliche Pflanzenfamilien, wydane w 1926 i w 1927 roku. Zakupiono 12 gatunków drzewek liściastych i tyleż iglastych z Zakładu Braci Hoser w Warszawie ${ }^{31}$.

Wiele czasu zajmowały dyrektorowi starania dotyczace codziennych, praktycznych spraw, o czym świadczy np. pismo do rektoratu z 4 lutego 1928 r.:

Wydział Mat.-Przyr. przyznał ogrodowi botanicznemu w 1923 r. 2 konie służące do robót w ogrodzie, wyjazdów kierownika i wycieczek botanicznych. Obecnie jeden z nich jest już bardzo stary i być może wkrótce padnie. Kierownik ogrodu botanicznego prosi o zakup nowego konia ${ }^{32}$.

Wyjątkowo mroźna zima roku 1928 bardzo uszczupliła kolekcję roślin gruntowych (zginęło ponad 350 gatunków) ${ }^{33}$. W roku akademickim 1929/1930 do najważniejszych inwestycji należało postawienie nowego muru na długości 90 metrów w miejscu starego, który groził zawaleniem ${ }^{34}$. Następnym ciężkim doświadczeniem stała się powódź wiosną 1931 roku.

${ }^{31}$ LCVA j.w. [Sprawozdanie z prac wykonanych w ogrodzie botanicznym U.S.B. w roku akademickim 1926/27].

${ }^{32}$ LCVA sygn. F. 175 I A nr 911 [Pismo dyr. ogr. bot. J. Trzebińskiego do rektoratu USB, 4 II 1928 r.].

${ }^{33}$ LCVA sygn. F. 175 I A nr 391, s. 57 [Sprawozdanie z działalności Ogrodu Botanicznego U.St.B. z roku akademickiego 1928/29].

${ }^{34}$ LCVA sygn. F. 175 VII B nr 52 [Sprawozdanie z działalności Ogrodu Botanicznego USB na folwarku Zakret w roku akad. 1929/30]. 
Wysiano wiosna 1931 r. do doniczek, na inspekta i do gruntu 1280 gatunków roślin; z tego wykiełkowało zaledwie 555 gatunków. Wiosną na skutek powodzi cały Ogród Botaniczny uległ silnemu zamuleniu: część zaś (około $1 / 3$ powierzchni) była zasypana piaskiem na głębokość od $1 / 2$ do 1 metra, przy tym zginęło około 150 gatunków. Odkopanie zasypanych roślin kosztowało wiele pracy i trudu. Nagromadzony zaś piasek użyto do wysypania dróg. [...] Rośliny szklarniane prawie zupełnie nie ucierpiały ${ }^{35}$.

Dla uzupełnienia strat $\mathrm{w}$ kolekcjach roślin rodzimych urządzano wycieczki w okolice Wilna. Większych remontów nie było z powodu znacznego ograniczenia funduszów. Niedługo później zbiory, powoli odbudowywane, doznały następnych zniszczeń z przyczyn klimatycznych. Z powodu bezśnieżnej i mroźnej zimy roku 1933/1934 oraz niezwykle suchej wiosny i lata - wiele roślin wyginęło lub silnie ucierpiało (ubyły 604 gatunki) ${ }^{36}$. Prowadzono głównie rutynowe prace nad odnowieniem i utrzymaniem kolekcji oraz funkcjonowaniem Ogrodu:

W roku sprawozdawczym prowadzono zwykłe roboty ogrodnicze: pielenie, podlewanie roślin i gracowanie ścieżek, malowanie nowych lub przemalowywanie starych etykietek. Większych remontów nie było, nie było również większych nabytków w roślinach żywych [...]. Ogród botaniczny zwiedzali słuchacze Uniwersytetu grupami i pojedynczo, a także przychodziły wycieczki szkół średnich i osoby prywatne. Były też udzielane objaśnienia ustne i piśmienne osobom zainteresowanym. W miarę zaś możliwości Ogród Botaniczny udzielał bezpłatnie nasion i żywych roślin ogrodom szkół średnich ogólnokształcących i rolniczych ${ }^{37}$.

${ }^{35}$ LCVA sygn. F. 175 VII B nr 52 [Sprawozdanie z działalności Ogrodu Botanicznego USB na folwarku Zakret od 1-go lipca 1930 roku do 1-go lipca 1931 r.].

${ }^{36}$ Ibidem, Sprawozdanie z działalności Ogrodu Botanicznego USB na Zakrecie pod Wilnem w roku akad. 1933/34.

${ }^{37}$ Ibidem. 
W roku akademickim 1936/1937 znacznie poprawiła się sytuacja sanitarna Ogrodu dzięki doprowadzeniu bieżącej wody ${ }^{38}$.

Inspektor Konstanty Prószyński przeszedł na emeryturę 31 lipca 1936 r., a niespełna miesiąc później po krótkiej chorobie zmarł w Wilnie 25 (lub 26) sierpnia 1936 r. Jego następcą został Andrzej Michalski (1904-1973), bliski współpracownik Trzebińskiego, pracujący od 1930 r. jako asystent w Zakładzie Systematyki Roślin ${ }^{39}$.

\section{Ostatnie lata 1937-1939}

Z dniem 1 maja 1937 r. przeszedł na emeryturę zasłużony dyrektor Trzebiński. W uznaniu zasług mianowany został 27 września 1938 r. profesorem honorowym Uniwersytetu Stefana Batorego ${ }^{40}$. Jego następcą został Franciszek Ksawery Skupieński (1888-1962) powołany 27 maja 1937 na kierownika Katedry (Zakładu) Systematyki Roślin USB, a 14 września 1937 r. mianowany profesorem nadzwyczajnym ${ }^{41}$. Absolwent Uniwersytetu Paryskiego (w wykonanej tam pracy doktorskiej opisał jako jeden z pierwszych w świecie rozmnażanie płciowe u śluzowców), po powrocie do kraju pracował na Uniwersytecie Warszawskim, gdzie uzyskał habilitację, i na Politechnice Warszawskiej. W czasie dwuletniej działalności w Wilnie prowadził m.in. studia nad śluzowcami oraz szkodnikami drewna i sposobami ich zwalczania. Pod jego kierownictwem kontynuowano rutynowe prace nad utrzymaniem Ogrodu.

W roku sprawozdawczym wykonano szereg prac nad uzupełnieniem nowymi gatunkami roślin już istniejących stanowisk roślinnych pod względem systematyki i ekologii roślin. Porządkowano zespoły roślinne i stworzono większe zbiorowisko roślin górskich. Wykonano zwykłe

${ }^{38}$ LCVA sygn. F. 175 VII B nr 232 [Sprawozdanie z działalności Ogrodu Botanicznego USB na Zakrecie pod Wilnem w roku akad. 1936/37].

${ }^{39}$ Zatrudniony na różnych stanowiskach asystenckich - zastępcy, młodszego i starszego asystenta od 1 X 1930, ostatni raz mianowany od 1 IX 1939 do 31 VIII 1940 r.). LCVA sygn. F. 175 A 14 nr 300 - Akta osobowe Andrzej Michalski. Mowszowicz 1966, s. 113.

${ }^{40}$ LCVA sygn. F. 175 I Bb nr 59 - Akta osobowe Józef Trzebiński.

${ }^{41}$ LCVA sygn. F. 175 I Bb nr 775 - Akta osobowe Franciszek Skupieński. Bukowiecki 1987. 
roboty ogrodowe: pielenie, podlewanie, gracowanie dróg i ścieżek, pisanie nazw roślin na tabliczkach metalowych, etykietowanie, zbieranie nasion. Przeprowadzono drobne remonty, jak malowanie części drewnianych w szklarni, w budynkach gospodarczych. Zmieniono rozpadające się lufciki w szklarni na nowe, urządzono nowe piece do ogrzewania i sys[tem] rur ogrzewających w zimnej szklarni. Kitowanie okien w szklarni it.d. ${ }^{42}$

W następnym roku (1938/1939) udało się poszerzyć Ogród o niewielki grunt $(0,2 \mathrm{ha})$, który przeznaczono na cele doświadczalne. Zrealizowano też inwestycje techniczne:

Rozszerzono system wodociagowy w szklarni. Wprowadzono instalację elektryczną do przedsionków szklarniowych oraz do kancelarii Ogrodu, również do kotłowni, do stajni, do wozowni i do składu na węgiel, również na dziedzińcu i w pracowni botanicznej Ogrodu. Kitowanie okien w szklarni it.d. Nabyto klacz do pracy w Ogrodzie Botanicznym oraz dołączono do Ogrodu Botanicznego nowy teren około $2000 \mathrm{mtr}^{2}$ [0,2 ha] teren ten został ogrodzony i założono na nim częściowo kultury doświadczalne ${ }^{43}$.

Na posiedzeniu Rady Wydziału 28 lutego 1939 r. prof. Skupieński referował projekt podziału posiadłości Zakret na tereny doświadczalne Wydziału Rolniczego oraz Ogrodu Botanicznego opracowany przez Komisję złożoną z przedstawicieli obu Wydziałów, w której skład weszli m.in.: prof. Skupieński, prof. Trzebiński i prof. Wiśniewskit ${ }^{44}$ W dniu 21 czerwca poparto prośbę Skupieńskiego o przyznanie dwóch etatów: furmana i pomocnika ogrodnika, a następnie wysłano w tej sprawie wniosek do Ministerstwa ${ }^{45}$. Począwszy od marca 1939 r. toczyła się sprawa

${ }^{42}$ LCVA sygn. F. 175 VII B nr 232 [Sprawozdanie z działalności Ogrodu Botanicznego USB na Zakrecie pod Wilnem w roku 1937/38].

${ }^{43}$ LCVA sygn. F. 175 VII B nr 198 [Sprawozdanie z działalności Ogrodu Botanicznego USB na Zakrecie pod Wilnem w roku 1938/39].

${ }^{44}$ LCVA sygn. F. 175 VII B nr 200 [Protokół nr 9 z posiedzenia Rady Wydz. Mat.-Przyr. USB z dnia 28 lutego 1939 r.].

${ }^{45}$ LCVA sygn. F. 175 VII B nr 230 [Pismo do Ministerstwa W.R. i O.P. z dn. 15 VII 1939 r.]. 
przyznania Ogrodowi nowej lokalizacji, ponieważ od dawna zdawano sobie sprawę z tego, że teren położony w bliskim sąsiedztwie rzeki jest stale zagrożony powodzią. Na posiedzeniu Rady Wydziału 27 czerwca 1939 roku uchwalono na wniosek dyrektora Skupieńskiego rozpoczęcie starań o przeniesienie Ogrodu Botanicznego.

[...] w związku z projektem prof. Skupieńskiego przeniesienia ogrodu botanicznego USB z obecnego nieodpowiedniego pod każdym względem terenu na teren właściwszy i związany bezpośrednio z miastem i z Lasem Zakretowym, Rada Wydziału Mat.-Przyr. USB zwraca się do Ministerstwa W. R. i O. P. z prośbą o uzyskanie od Skarbu Państwa i przekazanie na ten cel Wydziałowi Mat.-Przyr. USB terenów Państwowych zabudowanych drewnianymi domkami przez t.zw. czynszowników. Tereny te przylegają do Lasu Zakretowego i ograniczone są ulicą Zakretowa, Ogrodem Botaniki Lekarskiej USB z jednej strony, a ulicą Zakretową, rzeką Wilią i Cmentarzem ewangelickim i terenem Obserwatorium Astronomicznego z drugiej strony. - Uchwalono jednomyślnie $e^{46}$.

15 lipca 1939 roku wysłano do Ministerstwa prośbę o przyznanie nowego terenu, ale ze względu na wybuch II wojny światowej nigdy nie doszło do realizacji tej inicjatywy.

\section{Kolekcja roślin}

Sprawozdania roczne informuja o działach roślin, liczbie uprawianych gatunków w poszczególnych latach oraz nasion oferowanych do wymiany w wydawanych drukiem katalogach nasion. Ogólną koncepcję kolekcji przedstawił J. Trzebiński:

Zadaniem ogrodu jest możliwie zupełne skompletowanie ważniejszych i charakterystycznych gatunków flory województw wileńskiego i nowogrodzkiego, uzupełnienie

${ }^{46}$ LCVA sygn. F. 175 VII B nr 200 [Protokół nr 17 z posiedzenia Rady Wydz. Mat.-Przyr. USB z dnia 27 czerwca 1939 r., p. 8. Sprawa przyznania terenów na Ogr. Bot.]. 
kolekcji roślin obcokrajowych gruntowych zasługujących na uwagę, zgromadzenie ważniejszych roślin szklarniowych krajów egzotycznych ${ }^{47}$.

Położenie nacisku na gromadzenie roślin z okolic Wilna i Nowogródka wynikało nie tylko z ówczesnego rozwoju idei ochrony przyrody i tworzenia w wielu ogrodach botanicznych działów roślin określonych regionów dla celów ochroniarskich, dydaktycznych i popularyzatorskich. Posiadając mały obszar i dysponując bardzo skromnymi funduszami, można było stosunkowo tanim kosztem zgromadzić interesujacy zbiór, pozyskując w terenie żywe okazy lub nasiona.

W 1922 r. urządzono dla celów dydaktycznych pierwsze działy: systematyki ogólnej, flory krajowej oraz sztuczną wydmę przeznaczoną dla gatunków siedlisk piaskowych (psammofilnych) ${ }^{48}$. W roku akademickim 1924/1925 był już zaaranżowany dział roślin uprawnych oraz arboretum czyli kolekcja drzew i krzewów. W sprawozdaniu z tego roku podane są liczby gatunków dla poszczególnych grup:

1) dział systematyki ogólnej (rośliny przeważnie pozakrajowe) obejmuje już blisko 1000 gatunków, 2) dział roślin krajowych obejmuje 349 gatunków, 3) dział roślin uprawnych - 139 gatunków, 4) drzewa i krzewy (arboretum) ma 167 gatunków. Praca naukowa i wykorzystanie kolekcji. [...] praca naukowa polegała na utrzymywaniu w czystości i sprawdzaniu kolekcji roślin gruntowych, a także na uzupełnianiu ich nowymi gatunkami. Przez cały okres wegetacyjny ogród botaniczny dostarczał materiału do ćwiczeń i demonstracji ${ }^{49}$.

\footnotetext{
${ }^{47}$ Zestawienie wiadomości o kolekcji roślin zawiera sprawozdanie z roku akademickiego 1936/1937, w którym odchodzący na emeryturę dyrektor J. Trzebiński przedstawił ,zarys historii Ogrodu Botanicznego za lat 13, a mianowicie od roku 1924 do 1937”. LCVA sygn. F. 175 VII B nr 232 [Sprawozdanie z działalności Ogrodu Botanicznego USB na Zakrecie pod Wilnem w roku akad. 1936/37].

${ }^{48} \mathrm{Na}$ podstawie rocznych sprawozdań z działalności Ogrodu Botanicznego cytowanych wyżej. Wiadomości o kolekcji roślin podają też: Rydzewski 1929, ss. 336(64)338(66); Mowszowicz 1966, s. 113.

${ }^{49}$ LCVA sygn. F. 175 I A nr 152 [Sprawozdanie za rok akademicki 1924/25].
} 
Większość gatunków była oznakowana metalowymi tabliczkami, na których malowano farbą łacińskie (i prawdopodobnie również polskie) nazwy. W 1926 r. rozpoczęto budowę dużej szklarni (oddanej do użytku dopiero w 1929 r.), równocześnie zaczęto gromadzić rośliny cieplejszych regionów liczące w tym roku 153 gatunki. Przechowywano je „w małej szklarence, albowiem duża szklarnia dotąd nie posiada[ła] ogrzewania”. W roku akademickim 1927/1928 założono dział ekologii roślin $^{50}$, przy czym istniejąca już wcześniej wydma była ekspozycją o charakterze ekologicznym. W latach 1927-1929 powstało małe alpinarium, nazywane czasem alpinetum, oraz sztuczne torfowisko wysokie, na którym posadzono gatunki odpowiednie dla tego typu siedliska, m.in. modrzewnicę zwyczajną (Andromeda polifolia L.), tłustosz pospolity (Pinguicula vulgaris L.), żurawinę błotną (Oxycoccus palustris Pers.) i inne. Dla urozmaicenia krajobrazu usypano dwa wzgórza przeznaczone do obsadzenia drzewami. W odnowionym basenie poświęconym uprawie gatunków błotnych posadzono rośliny z okolic Wilna. W roku akademickim 1929/1930 powstała niewielka kolekcja bylin ozdobnych, a na dziale ekologii roślin zostały założone poletka z ,typami biologicznymi według Raunkiaera" ${ }^{51}$. Z większych przybytków posadzono w arboretum 66 gatunków drzew i krzewów oraz 24 okazy różnych odmian róż. Do szklarni przywieziono z krakowskiego Ogrodu Botanicznego 20 gatunków roślin ciepłych regionów. Polepszyło się oznakowanie gatunków, ponieważ sporządzonych zostało 165 sztuk tabliczek. „Prócz tego zostało u roślin gruntowych przez stosowne podkreślenie farba kolorowa zaznaczone ich geograficzne występowanie" ${ }^{52}$. W roku akademickim 1936/1937 w Ogrodzie znajdowały się następujące grupy roślin: „dział systematyki roślin krajowych i pozakrajowych, dział roślin

${ }^{50}$ Być może eksponowano tutaj różne sposoby zapylania kwiatu i rozsiewania nasion, tak jak było w krakowskim Ogrodzie Botanicznym.

${ }^{51}$ Obecnie określane mianem form życiowych. Są to morfologiczne typy roślin będące wyrazem ich przystosowania do warunków ekologicznych. Najbardziej znana klasyfikację form życiowych wprowadził dunski badacz Christen Raunkiaer (1905). Głównym kryterium tej klasyfikacji jest położenie zimujących pąków względem powierzchni gleby (Szweykowscy, red. 2003, ss. 230-231; Kornaś, Medwecka-Kornaś 2002, ss. $41-45,605)$.

${ }^{52}$ LCVA sygn. F. 175 VII B nr 52 [Sprawozdanie z działalności Ogrodu Botanicznego USB na folwarku Zakret w roku akad. 1929/30]. 
uprawnych, dział roślin rosnących na piaskach, dział ekologii roślin, arboretum, alpinarium i szereg innych działów pomniejszych"53. W r. 1938/1939 wymieniano ponadto grupę roślinności stepowej i piasków (być może dosadzono na wydmę również gatunki stepowe) oraz rośliny błotne uprawiane w basenach, podobnie jak rośliny wodne.

Tabela 1 zawiera zestawienie wszystkich działów i lat ich założenia. Odpowiadały one analogicznym grupom roślinnym w innych ogrodach botanicznych i były odzwierciedleniem prądów w nauce i dydaktyce. Podstawową rolę w nauczaniu odgrywał dział systematyki ogólnej. Wiedzy tej uczono w praktyczny sposób: na grządkach uprawiano rośliny reprezentujące poszczególne grupy systematyczne omawiane w czasie wykładów i ćwiczeń. Atrakcyjność nauczania systematyki zwiększyła się po wybudowaniu szklarni, gdzie eksponowano gatunki egzotyczne. Arboretum pozwalało na zapoznawanie się z podstawowymi gatunkami drzew i krzewów rodzimych oraz uprawianych w Polsce, podczas gdy dział roślin uprawnych-z ważnymi gatunkamiużytkowymi. Grupy pokazujące roślinność różnych typów siedlisk odzwierciedlały

Tabl. 1. Działy roślin w Ogrodzie Botanicznym USB ${ }^{54}$.

\begin{tabular}{|l|l|}
\hline \multicolumn{1}{|c|}{ Rok założenia } & \multicolumn{1}{c|}{ Dział } \\
\hline 1922 & Systematyki ogólnej \\
\hline 1922 & Flory krajowej \\
\hline 1922 & Rośliny piaskowe (psammofilne) \\
\hline $1924 / 1925$ & Rośliny uprawne \\
\hline $1927 / 1928$ & Ekologii roślin \\
\hline $1927-1929$ & Alpinarium \\
\hline $1927-1929$ & Torfowisko wysokie \\
\hline 1929 & Rośliny szklarniowe \\
\hline Lata 20. & Arboretum (drzewa i krzewy) \\
\hline Lata 20. & Gatunki wodne i błotne \\
\hline
\end{tabular}

${ }^{53}$ LCVA sygn. F. 175 VII B nr 232 [Sprawozdanie z działalności Ogrodu Botanicznego USB na Zakrecie pod Wilnem w r. akad. 1936/37].

${ }^{54} \mathrm{Na}$ podstawie rocznych sprawozdań Ogrodu Botanicznego USB z lat 1923/1924-1936/1937. 
Tabl. 2. Liczba gatunków roślin uprawianych w Ogrodzie Botanicznym w Wilnie ${ }^{55}$.

\begin{tabular}{|c|l|c|}
\hline $\begin{array}{c}\text { Rok } \\
\text { akad. }\end{array}$ & \multicolumn{1}{|c|}{$\begin{array}{c}\text { Działy lub więlksze kolekcje roślin } \\
\text { (liczba gatunków) }\end{array}$} & $\begin{array}{c}\text { Lączna } \\
\text { liczba } \\
\text { gatunków }\end{array}$ \\
\hline $1923 / 24$ & $\begin{array}{l}\text { Systematyka ogólna (823), Flora krajowa } \\
\text { (327), Rośliny uprawne (32), Arboretum } \\
\text { (drzewa i krzewy) (165) }\end{array}$ & 1347 \\
\hline $1924 / 25$ & $\begin{array}{l}\text { Systematyka ogólna (ok. 1000), Flora krajowa (349), } \\
\text { Rośliny uprawne (139), Drzewa i krzewy (167) }\end{array}$ & 1665 \\
\hline $1926 / 27$ & $\begin{array}{l}\text { Rośliny zielne (1874), Arboretum (72), Rośliny } \\
\text { szklarniowe (153) }\end{array}$ & 2099 \\
\hline $1928 / 29$ & & 1575 \\
\hline $1929 / 30$ & $\begin{array}{l}\text { Rośliny gruntowe (1531) - w tym przybytki róż } \\
\text { (24 odmiany), Rośliny szklarniowe (ok. 200) }\end{array}$ & 1731 \\
\hline $1930 / 31$ & & 2234 \\
\hline $1931 / 32$ & & 2244 \\
\hline $1933 / 34$ & & 2565 \\
\hline $1934 / 35$ & & 2509 \\
\hline $1935 / 36$ & $\begin{array}{l}\text { Arboretum (180), Rośliny szklarniowe (325), } \\
\text { byliny - przybytki gatunków i odmian (641) }\end{array}$ & 2490 \\
\hline $1936 / 37$ & $\begin{array}{l}\text { Rośliny gruntowe (ok. 2500), } \\
\text { Rośliny szklarniowe (ok. 300) }\end{array}$ & ok. 2800 \\
\hline
\end{tabular}

rozwój ekologii i fitosocjologii w nauce tego okresu. Znajdował się tu bowiem nie tylko dział ekologii roślin ilustrujący określone zjawiska, m.in. wspomniane typy biologiczne Raunkiaera, ale też sztucznie odtworzone zbiorowiska: roślinności piaskowej i torfowiskowej, a także fragmenty roślinności wodnej i błotnej. Kolekcję roślin systematycznie wzbogacano w zależności od wysokości otrzymanych funduszów, przy czym niesprzyjające pod względem klimatycznym lata przyczyniały się do strat. W latach 1923/1924-1926/1927 stan liczbowy kolekcji zaczął się powiększać od 1347 do 2099 gatunków (Tab. 2). Niestety,

${ }^{55} \mathrm{Na}$ podstawie rocznych sprawozdań Ogrodu Botanicznego USB z lat 1923/241936/37. Liczby, mimo że podane dokładnie, należy traktować jako przybliżone, co wynika z dużej dynamiki kolekcji w ogrodach botanicznych. Znajduje to wyraz w fakcie, że czasem w sprawozdaniach dla tego samego roku podawane są różne liczby. 
mroźna zima 1928 r. uszczupliła zbiory do 1575 gatunków. O ile powódź w 1931 r. nie przyczyniła się do obniżenia liczby gatunków (ponieważ straty uzupełniono okazami przesadzanymi z terenu), to bezśnieżna zima 1933/1934 i suche lato sprawiły, że stan liczbowy kolekcji zmniejszył się z 2565 do 2509. W r. 1936/1937 kolekcje powiększyły się do ok. 2800 gatunków. Oceniając stan zbiorów roślin wileńskiego Ogrodu Botanicznego, trzeba wziąć pod uwage jego niewielki obszar oraz trudne warunki, w jakich przyszło mu działać. Patrząc z tej perspektywy trzeba uznać ogrodowe kolekcje za bogate i urozmaicone. Dużą wartość miał dział flory krajowej dokumentujący różnorodność rodzimej flory, głównie na przykładzie okolic Wilna.

Źródłem materiału roślinnego były początkowo dziko rosnące gatunki pozyskiwane w czasie wycieczek. Wiele okazów otrzymano też od zaprzyjaźnionych ogrodów botanicznych, m.in. w Warszawie i Krakowie. Jak wspomniano wyżej, począwszy od roku 1923 zaczęto wydawać drukowane katalogi nasion oferowanych do wymiany, które ukazywały się pod różnymi tytułami ${ }^{56}$. Dzięki temu Ogród włączył się w krajową i międzynarodową wymianę nasion. Jak pisał J. Mowszowicz:

Nawet największe ogrody botaniczne chętnie korzystały z ofiarowywanych nasion wileńskiego ogrodu, gdyż ówczesny inspektor [...] Konstanty Prószyński niezmiernie skrupulatnie kontrolował zbiór nasion, doglądając starannego suszenia i selekcji ${ }^{57}$.

Tabela 3 zawierająca zestawienie zachowanych danych liczbowych dotyczących wymiany nasion pokazuje, jak wiele pracy wkładano w przygotowanie materiału roślinnego do wymiany i jak ważne rezultaty owa wymiana przynosiła. Tak na przykład w r. 1930/1931 wysłano 1700 paczek z nasionami do 142 ogrodów, natomiast otrzymano 1650 paczek od 62 ogrodów z różnych krajów. Nasiona zbierano głównie z roślin gruntowych rosnących w Ogrodzie lub ze stanu dzikiego. Skromna powierzchnia szklarni sprawiła, że uprawiano za mało okazów, żeby mogły wyprodukować dostateczną liczbę nasion do wymiany. Zdarzały się jednak lata, kiedy proponowano innym ogrodom egzotyczne gatun-

${ }^{56}$ Zobacz spis na końcu artykułu.

${ }^{57}$ Mowszowicz 1966, s. 114. 
ki, jak np. w roku 1932, kiedy oferowano alonsoę Alonsoa Warszenvicz̨ii (obecnie: A. warscewic そ̨i Regel) występującą dziko w Peru nazwaną na cześć zasłużonego ogrodnika krakowskiego Ogrodu Botanicznego Józefa Warszewicza (1812-1866), odkrywcy tego gatunku w Peru. W niektórych latach, np. w 1932 r., oferowano dość duży zbiór roślin rodzimych zebranych $\mathrm{w}$ terenie - było to prawdopodobnie spowodowane zamówieniami z innych ogrodów, gdzie interesowano się florą okolic Wilna, mało znaną w innych częściach świata.

Tabl. 3. Wymiana nasion Ogrodu Botanicznego USB z innymi ogrodami botanicznymi w Polsce i na świecie ${ }^{58}$. Objaśnienie: L. - liczba.

\begin{tabular}{|c|c|c|c|c|}
\hline \multirow[b]{2}{*}{$\begin{array}{l}\text { Rok } \\
\text { akad. }\end{array}$} & \multicolumn{2}{|c|}{$\begin{array}{c}\text { Ogród Botaniczny USB } \\
\text { - wysyłka nasion }\end{array}$} & \multicolumn{2}{|c|}{$\begin{array}{c}\text { Materiały otrzymane } \\
\text { od innych ogrodów } \\
\text { botanicznych }\end{array}$} \\
\hline & $\begin{array}{l}\text { L. wysłanych } \\
\text { katalogów nasion }\end{array}$ & 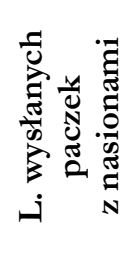 & 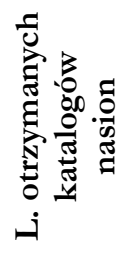 & 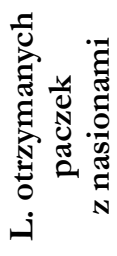 \\
\hline $1923 / 24$ & 64 & 962 & 49 & 604 \\
\hline $1926 / 27$ & 74 & 1040 & 61 & 1610 \\
\hline $1928 / 29$ & 140 & 1600 & 65 & 1900 \\
\hline $1929 / 30$ & 140 & 1650 & 62 & 1800 \\
\hline $1930 / 31$ & 142 & 1700 & 62 & 1650 \\
\hline $1931 / 32$ & $\begin{array}{l}140+24 \text { do różnych } \\
\text { ogrodów krajowych }\end{array}$ & 1520 & & 1900 \\
\hline $1933 / 34$ & $\begin{array}{l}128+52 \text { dla ogrodów } \\
\text { szkolnych w Polsce }\end{array}$ & 2180 & 98 & 2052 \\
\hline $1934 / 35$ & $\begin{array}{l}\text { 130+ } 40 \text { dla ogrodów } \\
\text { szkolnych w Polsce }\end{array}$ & 1750 & 200 & 1975 \\
\hline $1935 / 36$ & 120 & 3000 & & 2000 \\
\hline $1936 / 37$ & ok. 100 & ok. 3000 & ok. 100 & \\
\hline $1937 / 38$ & ok. 100 & ok. 3000 & ok. 100 & \\
\hline $1938 / 39$ & ok. 100 & ok. 3400 & ok. 100 & \\
\hline
\end{tabular}

${ }^{58}$ Na podstawie rocznych sprawozdań Ogrodu Botanicznego USB z lat 1923/24 1936/37. Podane liczby mają charakter przybliżony. 
Od początku swego istnienia kolekcja wykorzystywana była do celów dydaktycznych, przede wszystkim do nauczania studentów Uniwersytetu. W Zakładzie Botaniki Ogólnej odbywały się wykłady i ćwiczenia dotyczące podstawowych zagadnień, jak morfologia, anatomia, cytologia i fizjologia - w Ogrodzie można było demonstrować bogactwo form morfologicznych, podczas gdy na odbywające się w laboratorium ćwiczenia z anatomii i fizjologii dostarczano materiałów do obserwacji pod mikroskopem i robienia preparatów. W Zakładzie Systematyki Roślin koncentrowano się na systematyce roślin kwiatowych i zarodnikowych, geografii roślin, fizjologii i fitopatologii. Rozpoznawania gatunków i ich rozmieszczenia w terenie uczono na wycieczkach florystycznych, ale materiały do wykładów i ćwiczeń z fizjologii i fitopatologii pozyskiwano głównie z ogrodowych upraw. Z Ogrodu Botanicznego korzystały też częściowo uniwersyteckie jednostki o nastawieniu praktycznym: Zakład Ogólnej Uprawy Roli i Roślin oraz Zakład Farmakognozji i Hodowli Roślin Lekarskich, przy czym ten ostatni posiadał odrębny Ogród Roślin Lekarskich znajdujący się również na Zakrecie. Zakres udostępniania zbiorów Ogrodu Botanicznego stopniowo wzbogacano, np. w roku akademickim 1930/1931:

Wileński Ogród Botaniczny dostarczał stale podobnie jak w latach ubiegłych roślin żywych do ćwiczeń i demonstracji z różnych działów botaniki na wykładach. Do Ogrodu Botanicznego odbywały się wycieczki słuchaczy grupami i pojedynczo. Zwiedzały Ogród szkoły i osoby prywatne. W miarę możności udzielano nasion i sadzonek innym ogrodom botanicznym przy Zakładach szkolnych w Wilnie i okolicy. Były także i zapotrzebowania z b. Kongresówki. W roku ubiegłym podobnie jak i w poprzednich zostały przeprowadzone w Ogrodzie Botanicznym badania i doświadczenia z dziedziny fitopatologii ${ }^{59}$.

Oprócz celów dydaktycznych, ważne było również naukowe wykorzystanie zbiorów. O tym, że prowadzono tu doświadczenia z fitopatologii świadczy powyższa informacja z roku akademickiego 1930/1931. Badania Tomasza Majewskiego wykazały, że profesor Trzebiński i jego współpra-

${ }^{59}$ LCVA sygn. F. 175 VII B nr 52 [Sprawozdanie z działalności Ogrodu Botanicznego USB na folwarku Zakret od 1-go lipca 1930 roku do 1-go lipca 1931 roku]. 
cownicy prowadzili doświadczenia polowe (m. in. związane z odkażaniem ziarna zbóż i siemienia lnianego różnymi zaprawami) zakładane na poletkach w Ogrodzie Botanicznym ${ }^{60}$. W roku akademickim 1931/1932 „Ogród Botaniczny dostarczał materiału do nowo założonego ogólnego zielnika geobotanicznego Zakładu [Systematyki Roślin]”. O działalności dydaktycznej inspektora Prószyńskiego pisał po latach Mowszowicz:

Pamiętam wycieczki, które odbywałem wraz z Prószyńskim, [...] podczas których zbieraliśmy trawy i turzyce dla potrzeb Ogrodu Botanicznego, uczył mnie przy tym grzybów, podając praktyczne wskazówki oraz własne uwagi, ułatwiające rozpoznanie tych tak trudnych do oznaczania roślin ${ }^{61}$.

Krótki, zaledwie dziewiętnastoletni żywot Ogrodu Botanicznego, i to działającego w trudnych warunkach spowodowal, że ogród ten nie uzyskał tak dużego uznania, jak jego poprzednik z końca XVIII i początku XIX wieku. Trzeba podkreślić znaczenie dydaktyczne zbiorów, na których uczyło się roślin kilkanaście roczników studentów biologii i rolnictwa (jak wynika z rocznych, niekompletnych sprawozdań kierowników katedr było to około dwóch tysięcy osób). Nie można pominać znaczenia popularyzacji wiedzy przyrodniczej w szerokich kręgach społeczeństwa, zwłaszcza wśród młodzieży szkolnej. Ogród udostępniany był do zwiedzania uczniom, którzy mogli otrzymać do ogródków szkolnych żywe rośliny, nasiona oraz katalogi nasion. Może po części popularność starego Ogrodu Botanicznego na Zakrecie wśród mieszkańców Wilna przyczyniła się do tego, że nigdy nie został zlikwidowany i mimo burz dziejowych przetrwał do dzisiejszego dnia.

\section{6. Ślady ogrodu Botanicznego USB w dzisiejszym Vilniaus Universiteto Botanikos Sodas}

Po przyłączeniu Wilna do Litwy w 1939 r. władze litewskie zamknęły Uniwersytet Stefana Batorego, a do Wilna przeniosły litewski uniwersytet $z$ Kowna ${ }^{62}$. Nominalnie kierownictwo Ogrodu przejął Konstantin

${ }^{60}$ Opublikowane w Roczniku Ochrony Roślin A, 1: 1933, s. 78-83; tamże A, 2: 1935, s. 191-210; tamże 3: 1937, z. 4, s. 138-147.

${ }^{61}$ Mowszowicz 1966, s. 115.

${ }^{62}$ Uniwersytet im. Witolda Wielkiego, lit.: Vytauto Didžiojo universitetas. 


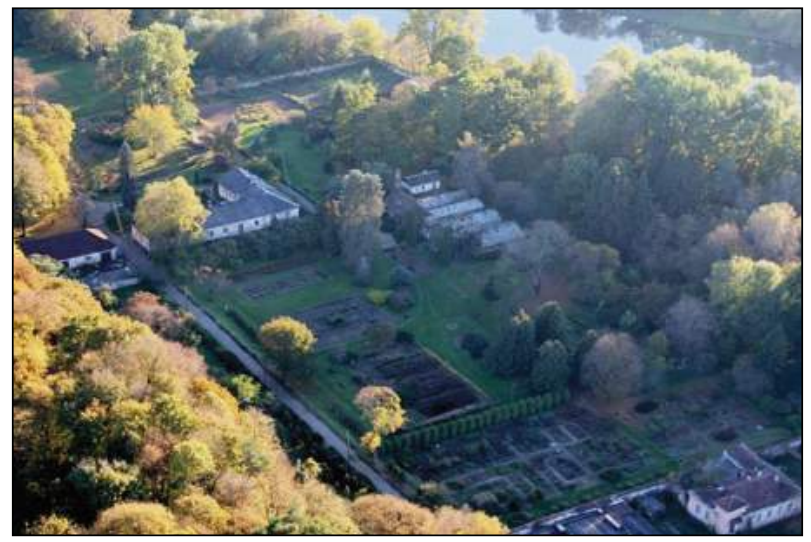

Ryc. 7. Widok z lotu ptaka dawnego Ogrodu Botanicznego USB - dzisiejszego działu „Vingis”- Vilniaus universiteto botanikos sodas na Zakrecie w Wilnie. Ze zbiorów Vilniaus universiteto botanikos sodas

Fig. 7. An aerial picture of the former Polish Botanic Garden of Stefan Batory University in Vilna - now 'Vingis' division of Lithuanian Vilniaus universiteto botanikos sodas at Zakret in Vilnius

Regel (1890-1970), dotychczasowy kierownik Ogrodu Botanicznego Uniwersytetu Kowieńskiego. Za rada polskiego personelu ogrodowego K. Regel powierzył pieczę nad Ogrodem Jakubowi Mowszowiczowi, który sprawował opiekę do czasu mianowania przez władze litewskie nowego kierownika. Został nim (w 1940 r.) mykolog i botanik Antanas Minkiewicz (Antanas Minkevičius 1900-1998), kierownik Katedry Systematyki Roślin Niższych ${ }^{63}$. Okupację niemiecką Ogród przetrwał bez większych zniszczeń. Niestety, podczas walk o Wilno w 1944 r. zarówno kolekcje, jak i szklarnie bardzo ucierpiały (w tym jedna została całkowicie zniszczona). Od ok. X 1944 do 1 VII 1945 roku (czyli do czasu wyjazdu z Wilna) wileńskim Ogrodem Botanicznym kierował Jakub Mowszowicz (jako docent katedry geobotaniki) wyznaczony na to stanowisko przez Radę Wydziałów Matematycznego, Chemicznego i Przyrodniczego litewskiego Państwowego Uniwersytetu Wileńskiego ${ }^{64}$. Po wojnie Ogród był raczej w złym stanie, a kolekcje obejmowały za-

${ }^{63}$ Vikipedija 2016b.

${ }^{64}$ Archiwum Uniwersytetu Lódzkiego: Tec₹ki osobowe pracownikón, sygn. 5140 - Jakub Mowszowicz. 
ledwie około 300 gatunków. Kolejny etap historii Ogrodu rozpoczął się w 1954 r., gdy Aldona Luczyńska (Aldona Lučinskienė) została mianowana jego kierownikiem. Funkcję tę pełniła do 1974 r. Do końca lat pięćdziesiątych XX w. uporządkowano dział systematyki roślin, kwiaciarstwa (roślin ozdobnych), dendrologii i pomologii, oraz alpinarium. W 1964 r. wybudowano trzy nowe szklarnie, a powierzchnię Ogrodu powiększono do 7,35 ha. Kolekcje ciagle wzbogacano nowymi gatunkami, tak że w 1971 r. ich liczba osiagnęła prawie 4000. Były to najlepsze lata w powojennej historii Ogrodu ${ }^{65}$. W 1974 r. założono nowy Ogród Botaniczny na wschód od Wilna, w Kairènai, o powierzchni prawie 150 ha. Tam przeniosła się dyrekcja i, ze zrozumiałych względów, główny punkt ciężkości działalności naukowej ${ }^{66}$. Ogród na Zakrecie stał się filią nowego Ogrodu i stracił swe dotychczasowe znaczenie.

Obecnie Ogród Botaniczny na Zakrecie (Ryc. 7-10 ) jest oddziałem Ogrodu Botanicznego Uniwersytetu Wileńskiego w Kairėnai. Posiada

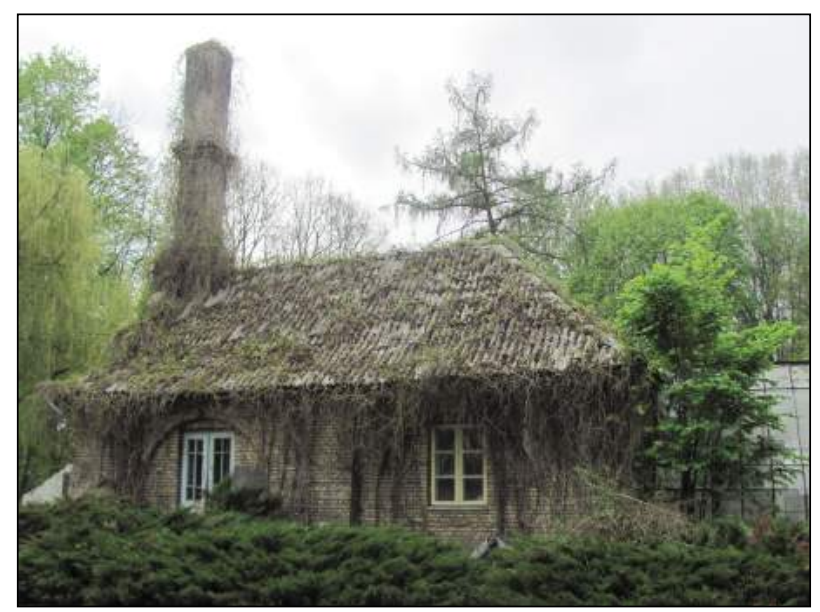

Ryc. 8. Budynek kotłowni przy dwóch szklarniach zbudowanych przez Uniwersytet Stefana Batorego w Wilnie - widok dzisiejszy (szklarnie są zrekonstruowane).

Fot. S. Žilinskaité, R. Juodkaitè

Fig. 8. Boiler house by two glasshouses built by Stefan Batory University in Vilna contemporary view (now glasshouses are reconstructed).

Photo by S. Žilinskaite, and R. Juodkaite

${ }^{65}$ Skridaila, Žilinskaitè 2009; Vikipedija 2016a.

${ }^{66}$ Skridaila 2001; Skridaila, Naujalis 2002. 


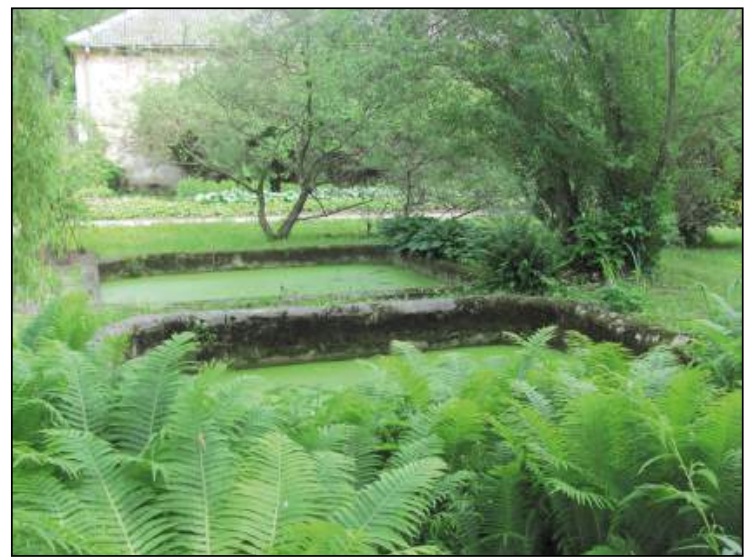

Ryc. 9. Baseny z czasów USB - widok obecny. Fot. S. Žilinskaitè, R. Juodkaitè Fig. 9. Experimental ponds from the time of Stefan Batory University in Vilna - contemporary view. Photo by S. Žilinskaité, and R. Juodkaité

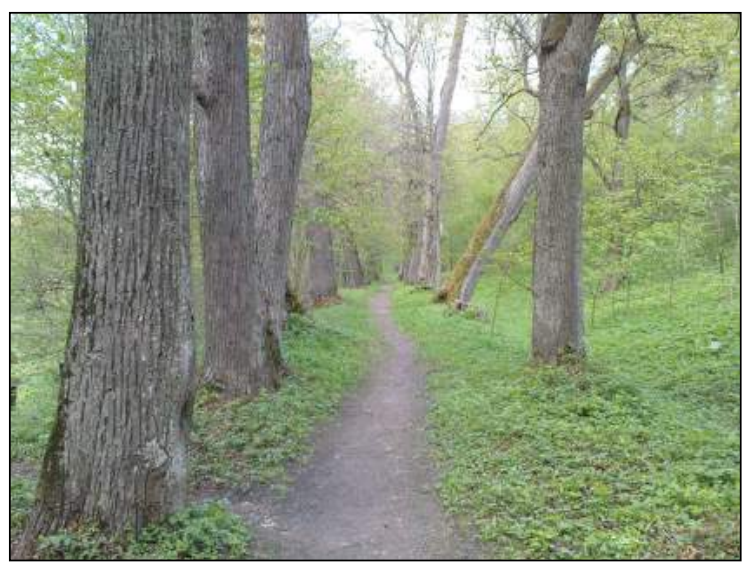

Ryc. 10. Aleja starych drzew w Ogrodzie na Zakrecie, 2011. Fot. P. Köhler Fig. 10. Old trees alley in the Garden at Zakret, 2011. Photo by P. Köhler

kilka działów: systematyki roślin, pomologiczny, roślin ozdobnych, a także arboretum oraz rosarium. Niestety, wysoka szklarnia na rośliny drzewiaste wygląda na nieużywaną od kilkunastu lat i popada w ruinę ${ }^{67}$. Nadal na zajęcia przychodzą tu studenci z pobliskiej Katedry Botaniki

${ }^{67}$ Köhler 2011. 
i Genetyki Uniwersytetu Wileńskiego. Częstym gościem jest też telewizja litewska, która relacjonuje ciekawsze przejawy kolejnych faz fenologicznych roślin. Ogród odwiedzany jest także przez publiczność. Kolekcje kwitnących roślin często służą do ozdabiania uniwersyteckich sal i uświetniania uroczystości.

\section{Podziękowania}

Dr Audrius Skridaila udostępnił do druku elektroniczne kopie obrazów roślin K. Prószyńskiego oraz współczesne fotografie Ogrodu Botanicznego w Wilnie - Vilniaus universiteto botanikos sodas, za co składamy mu serdecznie podziękowania. Dziękujemy również prof. dr hab. Tomaszowi Majewskiemu za udostępniene elektronicznej wersji książki Drieje poznania chorób roślin w Polsce (2016).

\section{SPIS WYBRANYCH KATALOGÓW NASION OGRODU BOTANICZNEGO USB ${ }^{68}$}

Delectus seminum quae hortus botanicus vilnensis Anno 1923 pro mutua commutatione offert. Vilno Polonia 1923, druk. „Lux” Wilno, ss. 6. ${ }^{69}$

Horti directoris officius fungens h.t. Facultatis Mathematices et Scientiarum Naturalium Decanus Prof. dr. E. Bekier, Horti inspector: K. Prószyński.

Zawierał nasiona 306 gatunków (w tym kilka odmian) z 50 rodzin.

Enumeratio seminum, quae hortus botanicus universitatis reg. Stephani Batorii ad mutuam commutationem offert. Vilnae, anno 1932. Zakłady graficzne „Znicz”, Wilno, ss. $14 .^{70}$

Prof. J. Trzebiński - Director Horti Botanici, Constantinus Prószyński Horti Inspector.

819 gatunków (w tym kilka odmian) z 56 rodzin.

\footnotetext{
${ }^{68}$ Katalogi zachowane w Bibliotece Jagiellońskiej.

${ }^{69}$ Sygn. 92579 II.

${ }^{70}$ Sygn. 103821 II 1932.
} 
Enumeratio seminum, quae hortus botanicus universitatis reg. Stephani Batorii ad mutuam commutationem offert. Vilnae, anno 1933. Zakłady graficzne „Znicz”, Wilno, ss. 15. ${ }^{71}$

Prof. Dr. J. Trzebiński - Horti Director, Constantinus Prószyński Horti Inspector.

935 gatunków (w tym kilkanaście odmian) z 64 rodzin.

Delectus seminum, quae permutationi offert Hortus Botanicus Universitatis Batoreanae in Wilno (Polonia) anno 1937. Ogród Botaniczny Uniwersytetu Stefana Batorego w Wilnie, Zakłady graficzne „Znicz”, Wilno, ss. $14 .^{72}$ Prof. Dr. J. Trzebiński - Director Horti Botanici, Mgr. Andrzej Michalski - Horti Inspector.

835 gatunków z 55 rodzin.

Delectus seminum, quae permutationi offert Hortus Botanicus Universitatis Batoreanae in Wilno (Polonia) anno 1937/1938. Ogród Botaniczny Uniwersytetu Stefana Batorego w Wilnie, Towarzystwo Wydawnicze „Pogoń”, drukarnia „Pax”, Wilno, ss. $14 .^{73}$

Prof. Dr. Franciszek Xawery Skupieński - Director Horti Botanici, Mgr. Andrzej Michalski - Inspector Horti Botanici.

835 gatunków z 74 rodzin.

Delectus seminum, quae permutationi offert Hortus Botanicus Universitatis Batoreanae in Wilno (Polonia) anno 1938/1939. Ogród Botaniczny Uniwersytetu Stefana Batorego w Wilnie, Towarzystwo Wydawnicze „Pogoń”, drukarnia „Pax”, Wilno, ss. 14. ${ }^{74}$

Prof. Dr. Franciszek Xawery Skupieński - Director Horti Botanici, Mgr. Andrzej Michalski - Inspector Horti Botanici.

785 gat. z 74 rodzin.

\footnotetext{
${ }^{71}$ Sygn. 103821 II 1933.

${ }^{72}$ Sygn. 103821 II 1937.

${ }^{73}$ Sygn. 103821 II $1937 / 38$.

${ }^{74}$ Sygn. 103821 II 1938/39.
} 


\section{ANEKS}

\section{Sprawozdanie z działalności Ogrodu Botanicznego U.St.B. $\mathrm{z}$ roku akademickiego $1928 / 29^{75}$}

Personel Ogrodu Botanicznego w roku sprawozdawczym:

Dyrektor Ogrodu: prof. J. Trzebiński

Inspektor : K. Prószyński

Niżsi funkcjonariusze: Antoni Jasiński - ogrodnik, Paweł Kowalewski - robotnik.

W roku sprawozdawczym zostały wykonane następujące prace. Wysiano do doniczek, do inspektów i do gruntu 840 gat., z tych wyrosło 460 gat., dosadzono drzewek i krzewów 28 gat., dosadzono w dziale ekologii 32 gat. Razem przybyło 520 gat.

W roku ubiegłym było w ogrodzie 1730 gatunków. Z liczby tej ubyło po wydaniu nasion (rośl. jednoroczne) 385 gat., zginęło z powodu silnych mrozów - 230 gat., razem ubyło 615 gat. Liczba gatunków zmniejszyła się obecnie o 155 gat. W roku obecnym ogólna ilość gatunków roślin wynosi 1575. Inne prace Ogrodu botanicznego: ukończono alpinetum i wysiano odpowiednie rośliny. Usypano dwa wzgórza dla drzewek. Urządzono miniaturowe torfowisko wyżynne z odpowiednimi roślinami kwiatowymi (Pinguicula vulgaris, Oxycoccus palustris, Andromeda polyfolia itp.). Wyreperowano basen dla roślin błotnych i posadzono tam nowe gatunki z okolic Wilna. Odnowiono małą szklarenkę. Nowa szklarnia (na razie jeden oddział) została w lutym r.b. zakończona i oddana do użytku Ogrodu Botanicznego. W maju przenoszono tam rośliny z małej szklarni. Inne remonty: pomalowanie dachu w domu dyrektora i drzwi w mieszkaniu inspektora.

Wymiana nasion przedstawia się w roku sprawozdawczym następująco: Ogród wileński wysłał do różnych ogrodów botanicznych katalog nasion, zawierających ok. 700 gat. ułożony w roku sprawozdawczym. Katalog ten wysłano do 140 ogrodów botanicznych, otrzymano zaś 65 katalogów z innych ogrodów. Porcji nasion wysłano 1600 sztuk, otrzymano 1900 sztuk. Do Ogrodu botanicznego odbyło się kilka wy-

\footnotetext{
${ }^{75}$ LCVA sygn. F. 175 I A nr 391 s. 57.
} 
cieczek ze słuchaczami Uniwersytetu i kilka wycieczek szkól średnich. Zwiedzały ogród także osoby prywatne pojedynczo i grupami, między innymi członkowie Uniwersytetu Katolickiego.

Ogród botaniczny dostarczał wreszcie materiału do ćwiczeń i pokazów na wykłady botaniki na przyrodzie, Studium rolniczym. W miarę możności udzielano też nasion i żywych roślin przy szkołach średnich w Wilnie i okolicach. Do biblioteki Ogrodu Botanicznego nabyto książek 20 tytułów. Większe dzieła: O. Penzig - Pflanzenteratologie 3 tomy, N. L. Britton and H. A. Brown - Illustrated Flora of the Northern United States, Canada and the British Possessions - 3 tomy. Prof. J. Trzebiński, Dyrektor Ogrodu. Wilno 26 VI 1929.

\section{Sprawozdanie z działalności Ogrodu Botanicznego USB na Zakrecie pod Wilnem w roku akad. 1936/37 ${ }^{76}$}

Skład osobowy Ogrodu Botanicznego

Dyrektor Ogr. Bot. Prof. J. Trzebiński

Inspektor Ogr. Bot. Mgr Andrzej Michalski

Niżsi pracownicy - ogrodnik Bolesław Korkuć, rzemieślnik Paweł Kowalewski. Prócz tego w miesiącach sezonowych pracowało od dwóch do trzech robotników.

Stan Ogrodu Botanicznego. Na terenie Ogrodu różne gatunki roślin sa zgromadzone albo z osobna na osobnych poletkach albo grupami na większych działkach. Powstały w ten sposób działy: dział systematyki roślin krajowych i pozakrajowych, dział roślin uprawnych, dział roślin rosnacych na piaskach, dział ekologii roślin, arboretum, alpinarium i szereg innych działów pomniejszych. Ogród posiada przeszło 2500 różnych gatunków rosnących na jego terenie. Szklarnie Ogrodu mają ponad 300 gatunków różnych roślin.

Ogród Botaniczny w roku bieżącym wydał katalog obejmujący przeszło 800 gatunków roślin przeznaczonych do wymiany z innymi Ogrodami Botanicznymi w kraju i zagranica. Katalogów nasion wysłano ponad 100 i otrzymano z innych ogrodów około 100. Do różnych Ogrodów Botanicznych drogą wymiany przesłano około 3000 tysięcy [sic!] paczek z nasionami.

\footnotetext{
${ }^{76}$ LCVA sygn. F. 175 VII B nr 232 s. 42-43.
} 
W roku sprawozdawczym prowadzono zwykłe roboty ogrodnicze: pielenie, podlewanie, gracowanie dróg i ścieżek, przygotowywano metalowe tabliczki z nazwami roślin koło 400. Szklarnie Ogrodu zostały zaopatrzone w sieć wodociagowa, również doprowadzono wodę do kancelarii na nowo założonej oraz urządzono ubikację ze zlewem. Przeprowadzono drobne remonty budynków szklarnianych i wybudowano skład na węgiel.

Ogród Botaniczny stale dostarcza materiału roślinnego do wszystkich ćwiczeń i wykładów.

Ogród Botaniczny zwiedzali słuchacze Uniwersytetu grupami i pojedynczo, a także przychodziły wycieczki ze szkół średnich. W miarę możności Ogród Botaniczny dostarcza bezpłatnie nasion i żywych roślin do Ogrodów szkół średnich.

Ponieważ Dyrektor Ogrodu Botanicznego obecnie kieruje Ogrodem Botanicznym prowizorycznie z powodu wyjścia na emeryturę dajemy tu krótki zarys historii Ogrodu Botanicznego za lat 13 a mianowicie od roku 1924 do 1937.

Teren dawnego Ogrodu Botanicznego, z którym związało się tyle tradycji, nie nadawał się zupełnie do założenia nowego Ogrodu Botanicznego. Na mocy uchwały Rady Wydziałowej i Senatu przydzielono Ogrodowi Botanicznemu w folwarku Zakret około dwóch hektarów ziemi, ogrodz[onej] od strony Wilii murem. Równocześnie Senat zastrzegł dla Ogrodu Botanicznego prawo dalszego zajmowania terenów przyległych w miare potrzeby. Pierwszym kierownikiem Ogrodu Botanicznego był prof. dr Piotr Wiśniewski. Na stanowisko inspektora mianowany został już w roku 1919 znawca flory kwiatowej i grzybków wyższych ziem północno-wschodnich Konstanty Prószyński. W roku 1920 zostały założone pierwsze działki w roślinami zielnymi oraz posadzone krzewy. Organizację Ogrodu przerwała inwazja bolszewicka. Po powrocie Uniwersytetu organizacja była prowadzona w dalszym ciagu i w roku 1922 założono dwa działy: dział roślin krajowych i dział systematyki ogólnej, również sztuczną wydmę z odpowiednią roślinnością. W roku 1923 prowizoryczne kierownictwo Ogrodu Botanicznego objął prof. dr Edward Bekier. W roku 1924 Rada Wydziałowa poleciła kierownictwo Ogrodu Botanicznego prof. dr Józefowi Trzebińskiemu.

Przystąpiono do założenia instalacji wodnej dla polewania roślin w Ogrodzie. W 1925 r. założono kolekcję roślin uprawnych. W roku 
1926 założono kolekcję ekologii roślin i zbudowano jeden większy basen i kilka pomniejszych. W roku 1926 rozpoczęto budowę szklarni większej. Z powodu wolnego napływu kredytów pierwszy oddział tej szklarni ukończony dopiero zostal w styczniu 1929 r. Drugi oddział zaczęto budować w 1928 r. W roku 1927 uzupełniono kolekcję drzew i krzewów, założono małe sztuczne torfowisko wysokie i rozpoczęto urządzanie małego zbioru roślin górskich. Do Ogrodu przydzielono wille na mieszkanie dla Dyrektora Ogrodu Botanicznego, mieszkanie dla inspektora i innych pracowników Ogrodu w domu murowanym oraz budynki do celów gospodarczych. Ogród posiada 4 mikroskopy oraz małą bibliotekę zawierającą około 200 tytułów. Zadaniem ogrodu jest możliwie zupełne skompletowanie ważniejszych i charakterystycznych gatunków flory województw wileńskiego i nowogrodzkiego, uzupełnienie kolekcji roślin obcokrajowych gruntowych zasługujących na uwagę, zgromadzenie ważniejszych roślin szklarniowych krajów egzotycznych.

Dyrektor Ogrodu Botanicznego USB prof. dr J. Trzebiński.

\section{Bibliografia}

\section{ŹRÓDŁA ARCHIWALNE}

ARCHIWUM UNIWERSYTETU ŁÓDZKIEGO:

Teczki osobowe pracowników: sygn. 5140 - Jakub Mowszowicz

LIETUVOS CENTRINIS VALSTYBESS ARCHYVAS [LITEWSKIE CENTRALNE ARCHIWUM PAŃSTWOWE W WILNIE] - w przypisach cytowane w skrócie: LCVA

AKTA UNIWERSYTETU STEFANA BATOREGO W WILNIE:

sygn. F. 175 A 14 nr 300 - Akta osobowe Andrzej Michalski.

sygn. F. 175 I A nr 911 - Zakłady Wydz. Mat.-Przyr.: Ogród Botaniczny 1923/24 $1936 / 37$.

sygn. F. 175 I A nr 152 - Sprawozdania roczne.

sygn. F. 175 I A nr 391 - Wydział Mat.-Przyr. Sprawozdania 1923/24-1933/34.

sygn. F. 175 I Bb nr 41 - Akta osobowe Konstanty Prószyński.

sygn. F. 175 I Bb nr 59 - Akta osobowe Józef Trzebiński. 
sygn. F. 175 I Bb nr 784 - Akta osobowe Piotr Wiśniewski.

sygn. F. 175 I Bb nr 775 - Akta osobowe Franciszek Skupieński.

sygn. F. 175 VII B nr 52 - Sprawozdania Wydz. Mat.-Przyr. 1929/30-1935/36.

sygn. F. 175 VII B nr 53 - Protokoły Rady Wydz. Mat.-Przyr. 1919/20.

sygn. F. 175 VII B nr 55 - Protokoły Rady Wydz. Mat.-Przyr. 1921/22.

sygn. F. 175 VII B nr 56 - Protokoły Rady Wydz. Mat.-Przyr. 1922/23.

sygn. F. 175 VII B nr 57 - Protokoły Rady Wydz. Mat.-Przyr. 1923/24.

sygn. F. 175 VII B nr 59 - Protokoły Rady Wydz. Mat.-Przyr. 1925/26.

sygn. F. 175 VII B nr 161 - Protokoły Rady Wydz. Mat.-Przyr. 1936/371937/38.

sygn. F. 175 VII B nr 198 - Wydz. Mat.-Przyr. Sprawozdanie za r. ak. 1938/39.

sygn. F. 175 VII B nr 200 - Protokoły Rady Wydz. Mat.-Przyr. 1938/39.

sygn. F. 175 VII B nr 230 - Ogród Botaniczny 1938.

sygn. F. 175 VII B nr 232 - Wydz. Mat.-Przyr. Sprawozdania roczne Zakładów 1936/37, 1937/38.

\section{OPRACOWANIA}

BALIŃSKI Michał

1835: Opisanie statystyczne miasta Wilna. Wilno: druk. J. Zawadzki.

BUKOWIECKI Henryk

1987: Skupieński Franciszek Ksawery (1888-1962). [W:] Stownik biologów polskich. Pod redakcja Stanisława Feliksiaka. Warszawa: Państwowe Wydawnictwo Naukowe. ISBN 83-01-00656-0.

CHLEBOWSKI Bronisław (red.)

1895: Stownik Geograficzny Królestwa Polskiego i Innych Krajów Stowiańskich. Warszawa: druk „Wieku”, t. XIV.

\section{GRĘBECKA Wanda}

1979: L'enseignement de la botanique à l'Université de Vilna (1781-1839). Kwartalnik Historii Nauki i Techniki 24(3), ss. 595-610.

1988: Badania szaty roślinnej prowadzone w ośrodku wileńskim i krzemienieckim (1781-1840), [W:] Wkeład wileńskiego ośrodka nankowego w prayrodnicze poznanie kraju (1781-1842). Pod redakcja Józefa Babicza i Wandy Grębeckiej. Wrocław - Warszawa - Kraków - Gdańsk - Łódź: Zakład Narodowy im. Ossolińskich, Wydawnictwo PAN. ISSN 0077-054X, ss. 115-225 („Monografie z dziejów nauki i techniki” 141).

1993: The Vilna school of botany (1781-1832). [W:] Studies on the history of botanical gardens and arboreta in Poland. Pod redakcja Alicji Zemanek i Bogdana Zemanka. Kraków: Polish Academy of Sciences, W. Szafer 
Institute of Botany. ISSN 0867-0749, s. 59-76 („Polish Botanical Studies, Guidebook Series" 9).

1998: Wilno-Krzemieniec. Botaniczna szkoła naukowa (1781-1841). Warszawa: Komitet Historii Nauki Polskiej Akademii Nauk. ISBN 83-908973-18 („Rozprawy z Dziejów Nauki i Techniki” 7).

JUNDZIŁ氏 Stanisław

1850: Gabinethistoryi naturalneji ogród botaniczny wileńskiego Uniwersytetu. Biblioteka Warszawska I, ss. 39-59.

HRYNIEWIECKI Bolesław

1937: Prof. dr Józef Trzebiński Czterdziestolecie pracy naukowej. Acta Societatis Botanicorum Poloniae 14(4), ss. 249-268, portr. k. 1 nlb. (Rés.: Le professeur dr. Józef Trzebiński. Note biographique à l'occasion du quarantenaire de son travail scientifique).

KLIMAVIČIUTE Jolita

1995: Józef Trzebiński - profesor Uniwersytetu Stefana Batorego. Lithuania 1(14), ss. 115-126.

\section{KÖHLER Piotr}

1991: Botanika w Krakowie i Wilnie w latach 1780-1840. Wszechswiat 92(1), ss. 10-13.

1994a: Collections of 18th Century Vilna Botanists in the Józef Jundziłł Herbarium. Botanical Journal of Scotland 46(4), ss. 589-593.

1994b: Old herbaria of Polish botanists in Vilna and Kiev. Taxon 43(3), ss. 487488.

1994c: Rośliny z terenu Białorusi w zielniku Józefa Jundziłła. Kwartalnik Historii Nanki i Technikei 39(3-4), ss. 93-102 (summ.: Plants collected in Byelorussia in the Józef Jundziłł herbarium).

1994d: Zielniki botaników ośrodka wileńskiego z lat 1780-1840 w Kijowie, Krakowie i Wilnie. Kwartalnik Historii Nauki i Techniki 39(1), ss. 109-116 (sum.: Herbariums of botanists from Vilnius centre in the years 17801840 (remained in Kiev, Cracow and Vilnius).

1994e: Zielniki botaników polskich w Wilnie i Kijowie zebrane przed rokiem 1840. Herbaria of Polish botanists collected before 1840 in Vilna and Kiev. Wiadomości Botaniczne 38(3/4), ss. 74-177.

1995a: Dawne ogrody botaniczne Wilna. Old botanic gardens in Vilna (Vilnius, Lithuania). Wiadomości Botaniczne 39(1/2), ss. 144-147.

1995b: Józef Jundziłł i jego zielnik. W szechświat 96(7-8), ss. 83-186.

1995c: Zielnik Józefa Jundzitta. Herbarium of Józef Jundzitt. Kraków: W. Szafer Institute of Botany, Polish Academy of Sciences. ISBN 83-85444-40-8 („Polish Botanical Studies, Guidebook Series” 13). 
1997a: Badania Józefa Jundziłła nad florą Litwy po 1830 r. (w świetle nieznanych materiałów rękopiśmiennych). Kwartalnik Historii Nanki i Techniki 42(1), ss. 43-74 (summ.: Józef Jundziłł's studies on flora of Lithuania after 1830 (on the basis of his unknown manuscript).

1997b: Biblioteka naukowa Józefa Jundziłła (1794-1877). Kwartalnik Historii Nauki i Techniki 42(3-4), ss. 63-84 (summ.: The scientific library of Józef Jundziłł (1794-1877)).

1997c: Herbarium of Józef Jundziłł (1794-1877). Taxon 46(2), ss. 365-366.

1999: Zielnik Józefa Jundziłła - addendum. Herbarium of Józef Jundziłł - addendum. Wiadomości Botaniczne 43(1/2), ss. 86-88.

2004: Józef Jundziłł (1794-1877). Materiały do biografii. Kwartalnik Historii Nauki i Techniki 49(1), ss. 83-117 (summ.: Józef Jundziłł (1794-1877). Materials for his biography).

2011: Dawne ogrody botaniczne Wilna - dwie dekady później. Old botanic garden in Vilna (Vilnius, Lithuania) - two decades later. Wiadomości Botaniczne 55(3/4), ss. 175-180.

L.R.

1871: $\quad$ Ogród botaniczny w Wilnie. Tygodnik Illustrowany ser. II VII(170), ss. 153154.

KORNAŚ Jan, MEDWECKA-KORNAŚ Anna

2002. Geografia roślin. Wydanie nowe. Warszawa: Wydawnictwo naukowe PWN. ISBN 83-01-13782-7.

MAJEWSKI Tomasz

2016: Dzieje poznania chorób roślin w Polsce. Warszawa: Wydawnictwo SGGW, Instytut Historii Nauki PAN, ss. 638.

MIENICKI Ryszard

1929: Pierwsze dziesięciolecie Uniwersytetu Stefana Batorego w Wilnie. [W:] Ksiega Pamiatkowa ku uczrzeniu CCCL rocznicy założenia i X wskrz̨eszenia Uniwersytetu Wileńskiego. T. II. Driesięciolecie 1919-29. Wilno: Nakł. Uniwersytetu Stefana Batorego, ss. 115(1)-158(44).

MOWSZOWICZ Jakub

1948-1951 [wyd. 1951]: Z historii dawnych ogrodów botanicznych Uniwersytetu Wileńskiego. (Contribution à l'histoire des anciens jardins botaniques de Wilno). Kosmos ser. A 66, ss. 209-230.

1966: Botanika i botanicy w Uniwersytecie Stefana Batorego w Wilnie w latach 1919-1939 (Przyczynki i wspomnienia). Studia i Materialy z. Driejón Nanki Polskiej Ser. B 12, ss. 99-124. (Rés.: La chaire de botanique et ses représentants à l'Université de Stefan Bator à Vilna en cours de la période de 1919 à 1939). 
1973: $\quad$ Prof. dr Piotr Wiśniewski (1881-1971). Wiadomości Botaniczne 17(2), ss. $75-77$.

PASZEWSKI Adam

1971: Profesor dr Piotr Wiśniewski w dziewięćdziesiąta rocznicę urodzin. Annales Universitatis Mariae Curie-Sktodowska Lublin - Polonia Sectio C 26, ss. I-X, k. 1 nlb. [portr. przed artykułem] + kk. 4 nlb. [dokumenty na końcu], [s. IX - „Wykaz prac Prof. dr Piotra Wiśniewskiego”].

\section{PORTAL INTERNETOWY „POZNAJ WILNO”}

2014-2015: „Park Zakret” („Park Vingis”). Publikacja dostępna online: http:// poznajwilno.pl/miasto/zabytki/kategoria-parki-pomniki/park-zakretpark-vingis/ (dostęp: 08. 09. 2016).

\section{RUTKOWSKA Irena}

1974: Józef Trzebiński. Wiadomości Botanicznne 18(4), ss. 237-240.

RYDZEWSKI Bronisław

1929: Wydział Matematyczno-Przyrodniczy U.S.B. w latach 1919-1929. [W:] Ksiega Pamiatkowa ku uczczeniu CCCL rocznicy zatożenia i X wskrzeszenia Uniwersytetu Wileńskiego. T. II. Dziesieciolecie 1919-29. Wilno: Nakł. Uniwersytetu Stefana Batorego, ss. 273(1)-376(104)

SKRIDAILA Audrius

2001: Introduction of woody plants in Vilnius University Botanical Garden in 17812000. Vilnius: Daktaro disertacijos santrauka.

SKRIDAILA Audrius, NAUJALIS J. R.

2002: Results of woody plant introduction in the Vilnius University Botanical Garden (1781-2000). Biologija 1, ss. 72-74.

SKRIDAILA Audrius, ŽILINSKAITE் Silva

2009: Vilniaus universiteto Botanikos sodas. Vilnius University Botanical Garden. [W:] Lietuvos botanikos sodai. Botanic gardens of Lithuania. Pod redakcją R. Žadeikienè. Vilnius: Vilniaus Universitetas.

SKRIDAILA Audrius, ŽILINSKAITE் Silva, SHIYAN Natalia

2015: Jean Emmanuel Gilibert and Vilnius University Botanical Garden: results of current studies of archive material from Vilnius archives, Göttingen University and National Herbarium of Ukraine (KW). Kwartalnik. Historii Nauki i Technikei 60(1), ss. 95-116. 
SLAWIŃSKI Witold

1947: X. Stanisław Bonifacy Jundziłł profesor Historii Naturalnej Wszechnicy Wileńskiej. The Rev. Stanisław Bonifacy Jundziłł Professor of Natural History in the University of Wilno. Annales Universitatis Mariae Curie-Sktodowska. Lublin - Polonia Sectio E 1, Suppl. I, ss. 1-208 + 13 tabl. nlb.

SZWEYKOWSCY Alicja i Jerzy (red.)

2003: Stownik botaniczny. Wyd. II, zmienione i uzupełnione. Warszawa: Wiedza Powszechna. ISBN 83-214-1305-6.

VIKIPEDIJA

2016a: Vingio parkas. Publikacja dostępna online: https://lt.wikipedia.org/ wiki/Vingio parkas (dostęp: 08. 09. 2016).

2016b: Antanas Minkevičius. Publikacja dostępna online: https://lt.wikipedia. org/wiki/Antanas Minkevičius (dostęp: 08. 09. 2016).

\section{WIŚNIEWSKI Piotr}

1938: †Konstanty Proszyński. Wspomnienie pośmiertne - Nachruf (Z portretem - Mit Bildnistafel). Acta Societatis Botanicorum Poloniae 15(4), ss. XXVII-XXIX [Nachruf s. XXIX], portr. k. 1 nlb.

WODZICZKO Adam

1926: Ogrody botaniczne w Polsce. [W:] Pamiętnik Jubileuszowej Wystawy Ogrodniczej w Poznaniu 25. IX-3 X 1926. Poznań: Nakł. Komitetu Jubileuszowej Wystawy Ogrodniczej, ss. 44-59. 
